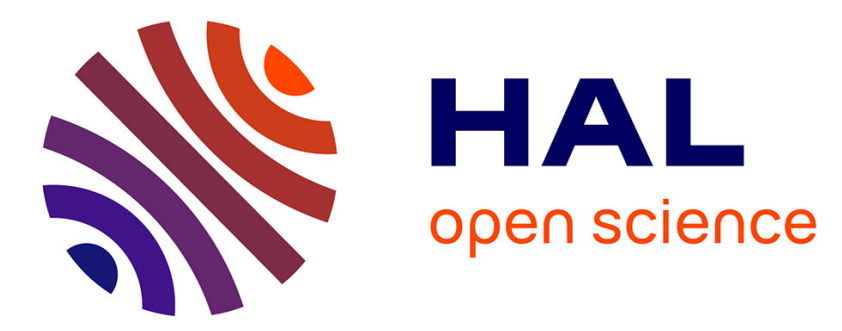

\title{
Results of Field Research on Ancient Stonework in the River Valleys of Bortala and Ili in Western Tian Shan (Xinjiang, China)
}

\author{
Annie Chan, Dexin Cong
}

\section{- To cite this version:}

Annie Chan, Dexin Cong. Results of Field Research on Ancient Stonework in the River Valleys of Bortala and Ili in Western Tian Shan (Xinjiang, China). Asian Perspectives, 2020, 10.1353/asi.2020.0019 . hal-03220788

\section{HAL Id: hal-03220788 \\ https://hal.science/hal-03220788}

Submitted on 7 May 2021

HAL is a multi-disciplinary open access archive for the deposit and dissemination of scientific research documents, whether they are published or not. The documents may come from teaching and research institutions in France or abroad, or from public or private research centers.
L'archive ouverte pluridisciplinaire HAL, est destinée au dépôt et à la diffusion de documents scientifiques de niveau recherche, publiés ou non, émanant des établissements d'enseignement et de recherche français ou étrangers, des laboratoires publics ou privés. 


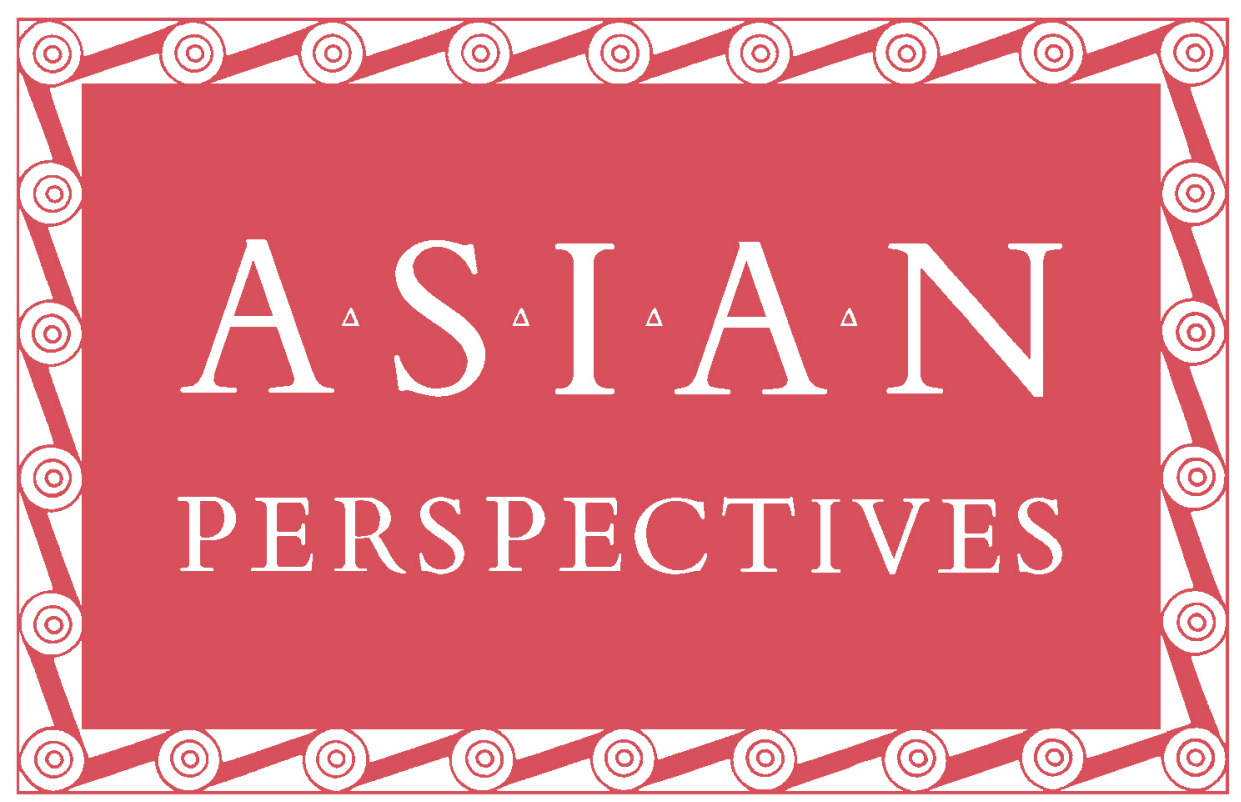

The Journal of Archaeology

for Asia and the Pacific

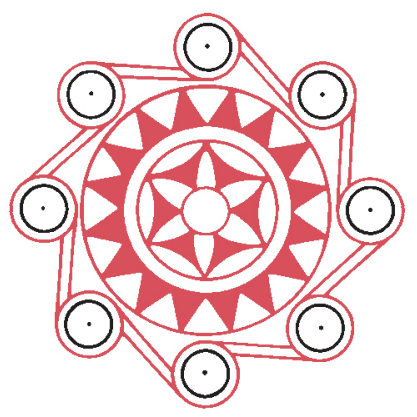

Volume 59 Number 22020 


\section{ASIAN PERSPECTIVES}

The Journal of Archaeology for Asia and the Pacific

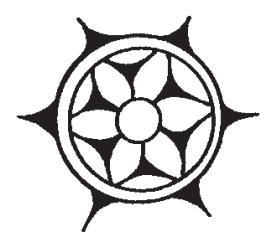

Editors' Note

ARTICLES

Skeletal and Dental Health of Precontact Marquesans: The

Bioarchaeology of the Human Skeletons from Ha'atuatua,

Nuku Hiva, Marquesas Islands

Michael Pietrusewsky, Michele Toomay Douglas, and

Rona Michi IKEHARA-QueBraL

Settlement Relocation, Urban Construction, and

Social Transformation in China's Central Plain, 2300-1500 B.C.

Liye XIE, Zahid DaudjeE, Chun Fu LiU, and Pauline Sebillaud

SPECIAL SECTION: PREHISTORIC STONE REMAINS IN XINJIANG

(CHINA) AND MONGOLIA AND THEIR SYMBOLIC LANDSCAPES: UPDATES FROM FIELD RESEARCH

Modules of Stone Construction and the Building of Ritual and Social Traditions in Prehistoric Xinjiang (China) and Mongolia Annie CHAN

Archaeological Research in the Ili Region: A Review

ZHANG Chi and Marcella FESTA

Results of Field Research on Ancient Stonework in the

River Valleys of Bortala and Ili in Western Tian Shan

(Xinjiang, China)

Annie Chan and Dexin Cong 
Quantifying Ritual Funerary Activity of the Late Prehistoric

Southern Kanas Region (Xinjiang, China)

Gino CASPARI

Advancing Archaeological Research of the Mongolian

Altai through the Scientific Study of Deer Stones:

New Discoveries from Buyant Valley

Alexey A. TishkiN

BOOK REVIEWS

Afetna Point, Saipan: Archaeological Investigations of a Latte Period Village and Historic Context in the Commonwealth of the Northern Mariana Islands Yellow Beach 2 after 75 Years: The Archaeology of a WWII Invasion Beach on Saipan and its Historic Context in the Commonwealth of the Northern Mariana Islands

Reviewed by James M. BAYMAN

The Affect of Crafting: Third Millennium BCE Copper

Arrowheads from Ganeshwar, Rajasthan

Reviewed by Peter JOHANSEN

The Politics of the Past in Early China

Reviewed by Lothar VON FALKENHAUSEN

World Heritage and Human Rights: Lessons from the

Asia-Pacific and Global Arena

Reviewed by Michael HERZFELD

Prehistory and Archaeology of Northeast India: Multidisciplinary

Investigation in an Archaeological Terra Incognita

Reviewed by Kathleen D. MORRISON

Stone Beads of South and Southeast Asia: Archaeology,

Ethnography, and Global Connections

Reviewed by Heidi MUNAN

The Archaeology of Afghanistan: From Earliest Times

to the Timurid Period

Reviewed by J. Mark KENOYER 


\section{Results of Field Research on Ancient Stonework in the River Valleys of Bortala and Ili in Western Tian Shan (Xinjiang, China)}

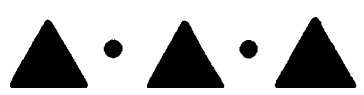

Annie Chan and Dexin CONG

ABSTRACT

Ground-level stone structures constructed of unworked or minimally shaped slabs and cobbles are a ubiquitous feature of the archaeological landscape of western Tian Shan. However, little is known about their architecture other than surface morphology, which can appear quite homogeneous. This article presents the latest results of surveys and excavations of selected clusters of Bronze Age stonework from the contiguous Bortala River Valley and Ili River Valley in Xinjiang Uyghur Autonomous Region, China. In examining the distinctive forms and layouts applied to different building functions, including burial and habitation, we delve into regional variations in construction and land use straddling the intermontane valleys. In Bortala, the configuration and characteristics of the building components evince cumulative phases of use and construction on staggered timescales resulting from the aggregation of burials, repurposing of building parts, and designation of specific locales as alternately transhumant encampments and sites of burial and commemoration of broad social networks and lineal relations. In comparison, the architectural remains in Ili reflect a prolonged temporality that correlates with sedentary agricultural practices, diversified space use, and localized craft production and exchange. The field research provides important data for identifying autochthonous features of building practices independent of existing typologies of highly homogenized architectural schemas to inform broader contexts of subsistence patterns and social customs that resurgent interests in the Andronovo of Xinjiang seek to address. KEYWORDS: stone architecture, habitation, funerary customs, western Tian Shan, Bronze Age Xinjiang, Andronovo Culture.

\section{INTRODUCTION}

RECENT ARCHAEOLOGICAL FIELD RESEARCH ON THE ANCIENT STONE STRUCTURES that are scattered across the montane grasslands of today's Xinjiang Uyghur Autonomous Region has yielded a large corpus of new materials pertinent to the study of settlement and funerary activities in western Tian Shan (Caspari, Betts et al. 2017; Chan 2017a; Chen 1990, 2017; Guo 2011; Jia et al. 2017). The majority of field campaigns

Annie Chan (https://orcid.org/0000-0002-4435-3209) is Assistant Professor at the Institute of Sinology, Department of Asian Studies, Ludwig Maximilian University of Munich and Foreign Associate Member at the East Asian Civilizations Research Center (CRCAO), France. Dexin Cong is Researcher and Head of Department of Frontier Archaeology at the Institute of Archaeology, Chinese Academy of Social Sciences. 
investigating structural remains have been carried out in the contiguous river valleys of Bortala and Ili ( Fig. 1, Fig. 2). These have integrated excavations with extensive field surveys and aerial imaging, a distinct methodological shift from the traditional approach in Xinjiang archaeology centered around threatened burial sites (IA CASS et al. 2013; Jia X. 2019; Wang Y. et al. 2019; XIA 2002, 2012a, 2012c, 2013, 2014a, 2014b, 2017; XIA et al. 2008). The findings are considerable and herald a shift in research focus from this disproportionate attention placed on burials and funerary artifacts that has been engendered by salvage archaeology toward habitation and settlement patterns. Despite the importance of these momentous findings, particularly with regard to structural remains, they are still only scantily presented in English and international publications.

To rectify this gap in the international literature, this article presents a comparative analysis of key findings from the northern mountain chains of western Tian Shan, that is, in Bortala Mongol Autonomous Prefecture (Bo’ertala Menggu zizhizhou 博爾塔拉 蒙古自治州) and Ili Kazakh Autonomous Prefecture (Yili Hasake zizhizhou 伊犁哈 薩克自治州). Our discussion is centered on the primary results of survey and excavation from the sites of Aduuchuluu and Husita in Bortala Valley (Fig. 1), supplemented with a synthesis of the most recent archaeological output from fieldwork conducted along Kashi River in Ili Valley (Fig. 2). Here, we focus on structural remains dated to the second millennium B.C.E., which have important implications for understanding the influence of the Eurasian Andronovo Culture on Bronze Age Xinjiang.

Series of radiocarbon dates collected from multiple sites across western Xinjiang have provided new grounds for reassessing the timeline and pattern of Andronovo's purported eastward spread into Xinjiang, namely, that Andronovo-type remains in Xinjiang predate their western counterparts (Cong et al. 2017) (Table 1). At the same time, the variability of Bronze Age cultures in eastern Xinjiang is showcased through new excavation results that have inspired the coining of new type sites and typologies (Chen 2017; Guo 2011; Jia, Betts, Cong et al. 2017; Ruan 2012; Tan 2011). The theories of Xinjiang's connection to prehistoric Bronze Age cultures of Eurasia that dominated the first wave of archaeological research in the 1980s and 1990s are once again brought to the fore (e.g., Chen and Hiebert 1995; Mei and Shell 1999, 2002). With the publication of monographs by Chen Ge (2017), Han Jianye (2007), Guo Wu (2011), Yang Jianhua and colleagues (2009), and others, combined with a plethora of themed essay collections and primary site reports centered on results of new regional surveys and excavations, the central question of Andronovo Culture in Xinjiang is now being reexamined in broadened interregional contexts incorporating other Bronze Age cultures of Xinjiang, specifically Qiermu'erqieke (Chermuchek) and Xiaohe (Jia and Betts 2010; Jia, Betts and Abuduresule 2019), along with Eurasian cultures of allochthonous origins, in particular Okunevo, Andronovo, and Karasuk (Kuzmina 2007:ch. 20; Lin 2011; Ruan 2013; Shao 2009). Building on this body of research, this article examines a new corpus of field data from western Tian Shan, the geographical center of this revived discourse on Andronovo, by drawing substantially on Chinese site reports currently underrepresented in the literature.

The object of study is prehistoric stone structures partially exposed on the surface; earthen mounds are also taken into account where applicable. The stone structures cluster mainly on piedmont floors and lower river terraces on south-facing slopes flanking primary watercourses (see Fig. 3 for examples in Bortala Valley). The main 


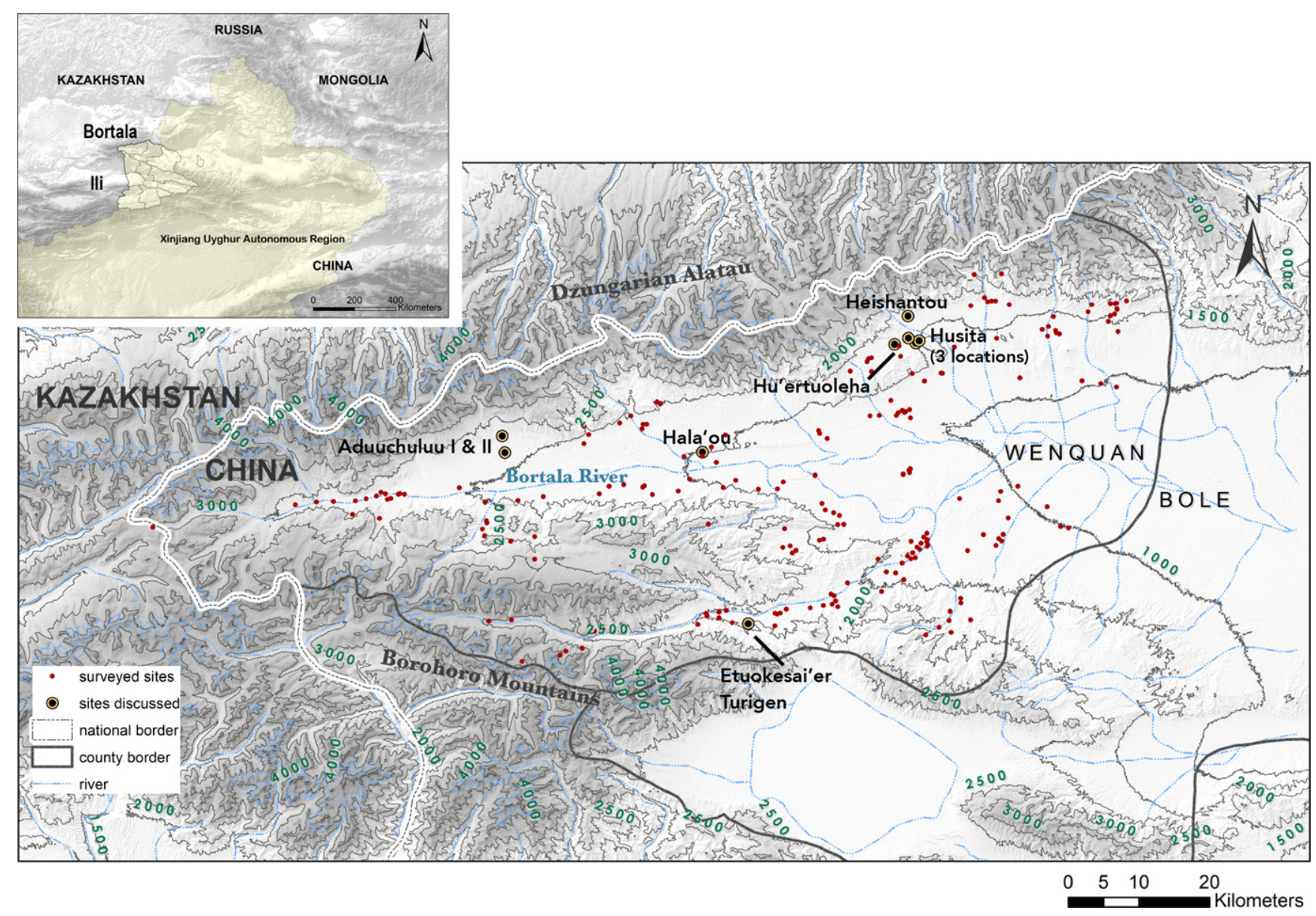

Fig. 1. Documented sites in the Bortala River Valley; inset map shows location of Xinjiang Uyghur Autonomous Region in China (maps by Annie Chan). 


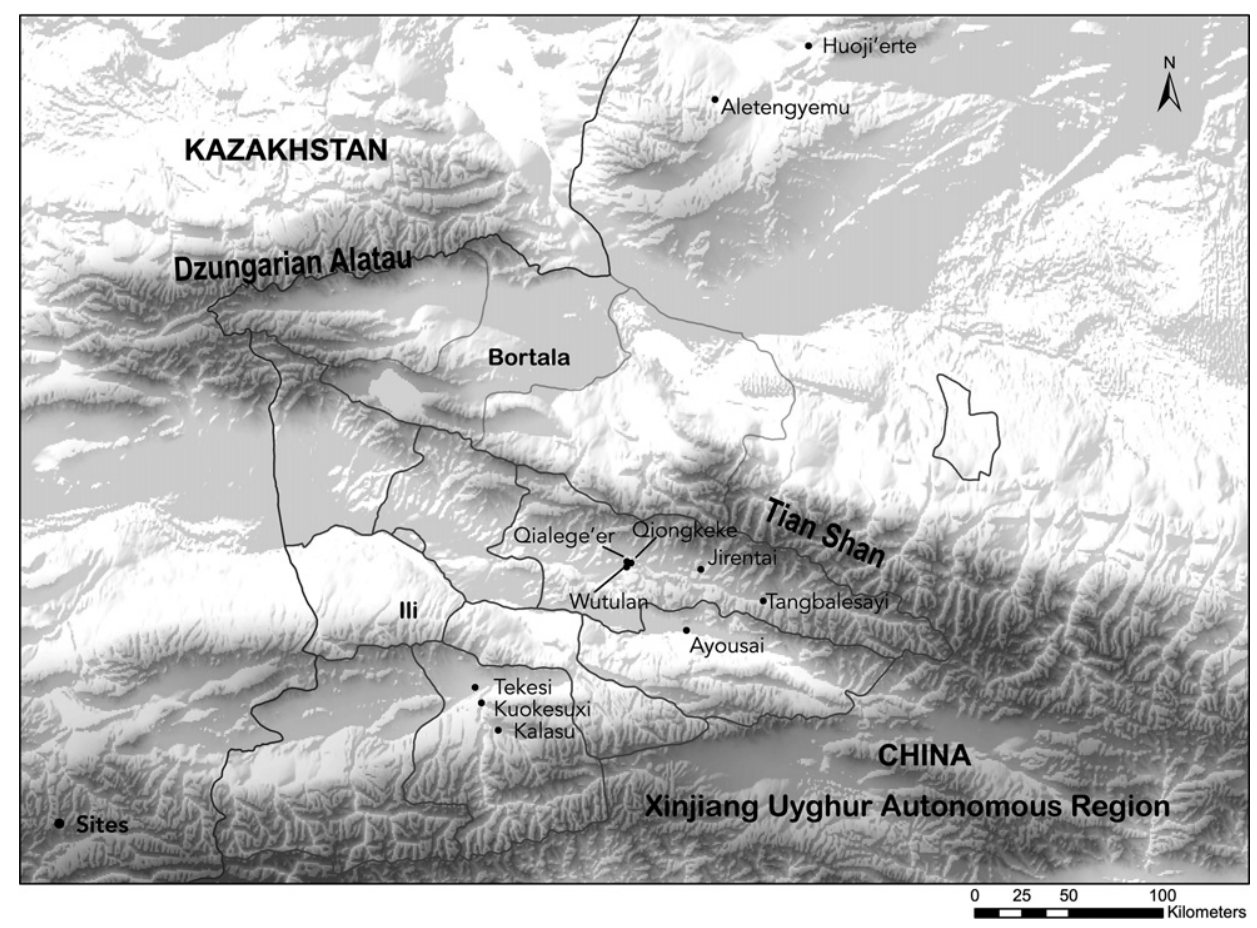

Fig. 2. Bronze Age sites in Ili River Valley, including sites with radiocarbon dates (map by Annie Chan).

building components are cobbles and rough-cut granite slabs of varying sizes provisioned from local sources of raw stone materials. A single construction unit usually consists of a quadrilateral or circular stone enclosure encompassing a burial space comprising shafted pits, cist graves, and wooden coffins (occasionally in side chambers); the enclosure is usually delineated by a surface stone circle or covered by a cairn. Compound structures are made up of multiple quadrangular enclosures with connected and shared perimeters. There may be fewer than ten or as many as several hundred structures at any given cluster location.

We compare how structural layout correlates with terrain and how building design informs the history of site use in the contiguous Bortala and Ili river valleys. We examine the patterns of clustering, diversity of structure types, burial forms, and characteristics of material finds in funerary and habitation contexts. Our analysis shows that the variability in built form and building function is represented not only by subsistence-driven principles of space use and organization but also stems from the temporalities of architectural practices that were shaped by the sequence of constructions of lineal and social relations through time. The different architectural landscapes of Bortala and Ili provide evidence for heterogeneity in the material culture of western Tian Shan. These findings behoove us to take more diverse approaches to analyzing the intermontane archaeological record and to critically evaluate research questions centering around Andronovo Culture. 
Table i. Radiocarbon Dates from Sites in Xinjiang with Materials Attributed to Bronze Age Andronovo Culture

\begin{tabular}{|c|c|c|c|c|}
\hline SITE & $\begin{array}{l}\text { CALIBRATED DATE } \\
\text { RANGE (B.C.E.) }\end{array}$ & $\begin{array}{l}\text { PROBABILITY } \\
(\%) \\
\end{array}$ & $\begin{array}{c}\text { SAMPLE } \\
\text { MATERIAL }\end{array}$ & REFERENCE \\
\hline Aletengyemule & $\begin{array}{l}1760-1640 \\
2550-2340\end{array}$ & $\begin{array}{l}67.2 \\
64.5\end{array}$ & $\begin{array}{l}\text { Human bone } \\
\text { Human bone }\end{array}$ & Cong et al. 2017; XIA 2017 \\
\hline Ayousai & $\begin{array}{l}1410-1260 \\
1410-1260\end{array}$ & $\begin{array}{l}95.4 \\
95.4\end{array}$ & $\begin{array}{l}\text { Animal bone } \\
\text { Animal bone }\end{array}$ & Wang Y. et al. 2019; XIA 2013 \\
\hline $\begin{array}{l}\text { Husita } \\
\qquad \text { (Harulu } \\
\text { Cemetery) }\end{array}$ & $\begin{array}{l}591-413 \\
1023-912 \\
1501-1426 \\
1505-1430 \\
1613-1509 \\
1640-1527 \\
1660-1530 \\
1666-1597 \\
1666-1597\end{array}$ & $\begin{array}{l}51.5 \\
95.4 \\
95.4 \\
95.4 \\
95.4 \\
95.4 \\
95.4 \\
63.4 \\
63.4\end{array}$ & $\begin{array}{l}\text { Bone }^{\mathrm{a}} \\
\text { Human bone } \\
\text { Human bone } \\
\text { Human bone } \\
\text { Human bone } \\
\text { Human bone } \\
\text { Human bone } \\
\text { Human bone } \\
\text { Human bone }\end{array}$ & $\begin{array}{l}{ }^{14} \text { C Lab-IA-CASS et al. } \\
\text { 2019; Jia X. } 2019\end{array}$ \\
\hline Huoji'erte & $1640-1530$ & 68.2 & Human bone & Cong et al. 2017 \\
\hline Jirentai & $\begin{array}{l}1211-1020 \\
1211-1056 \\
1231-1055 \\
1451-1291 \\
1508-1411 \\
1613-1491 \\
1616-1493 \\
1623-1496 \\
1626-1497 \\
1629-1500 \\
1640-1505 \\
2504-2399 \\
2575-2466 \\
2631-2474\end{array}$ & $\begin{array}{l}95.4 \\
95.4 \\
95.4 \\
95.4 \\
95.4 \\
80.5 \\
87.8 \\
92.7 \\
93.8 \\
95.4 \\
95.4 \\
54.5 \\
95.4 \\
93.4\end{array}$ & $\begin{array}{l}\text { Animal bone } \\
\text { Human bone } \\
\text { Human bone } \\
\text { Charred seed } \\
\text { Animal bone } \\
\text { Caprid metatarsal } \\
\text { Animal bone } \\
\text { Animal bone } \\
\text { Animal bone } \\
\text { Animal bone } \\
\text { Animal bone } \\
\text { Wood charcoal } \\
\text { Wood charcoal } \\
\text { Wood charcoal }\end{array}$ & $\begin{array}{l}\text { Wang \& Ruan 2016; } \\
\text { Wang Y. et al. 2019; XIA } 2017\end{array}$ \\
\hline Kalasu & $\begin{array}{l}120-238 \\
1209-979 \\
1210-1028 \\
1265-1110\end{array}$ & $\begin{array}{l}89.8 \\
95.4 \\
95.4 \\
95.4\end{array}$ & $\begin{array}{l}\text { Animal bone } \\
\text { Animal bone } \\
\text { Animal bone } \\
\text { Animal bone }\end{array}$ & $\begin{array}{l}\text { Wang Y. et al. 2019; } \\
\text { XIA et al. } 2008\end{array}$ \\
\hline Kuokesu(he)xi & $\begin{array}{l}1010-820 \\
1680-1490 \\
1740-1530 \\
1740-1530 \\
1770-1610\end{array}$ & $\begin{array}{l}95.4 \\
95.4 \\
95.4 \\
95.4 \\
95.4\end{array}$ & $\begin{array}{l}\text { Human bone } \\
\text { Human bone } \\
\text { Wood } \\
\text { Wood } \\
\text { Wood }\end{array}$ & XIA $2012 d$ \\
\hline $\begin{array}{l}\text { Ningjiahe- } \\
\text { shuiku }\end{array}$ & $\begin{array}{l}1320-1250 \\
1465-1430\end{array}$ & $\begin{array}{l}39.9 \\
42.3\end{array}$ & $\begin{array}{l}\text { Human bone } \\
\text { Human bone }\end{array}$ & Cong et al. 2017 \\
\hline Qialege'er & $\begin{array}{l}1620-1500 \\
1620-1500\end{array}$ & $\begin{array}{l}95.4 \\
95.4\end{array}$ & $\begin{array}{l}\text { Animal bone } \\
\text { Animal bone }\end{array}$ & $\begin{array}{l}\text { Wang Y. et al. 2019; } \\
\text { XIA } 2014 a\end{array}$ \\
\hline Tangbalesayi & $\begin{array}{l}1605-1585 \\
1620-1495\end{array}$ & $\begin{array}{l}95.4 \\
95.4\end{array}$ & $\begin{array}{l}\text { Horse bone } \\
\text { Human bone }\end{array}$ & $\begin{array}{l}\text { Wang Y. et al. 2019; } \\
\text { XIA 2012a, 2012b }\end{array}$ \\
\hline
\end{tabular}

(Continued) 
TABLE 1. (Continued)

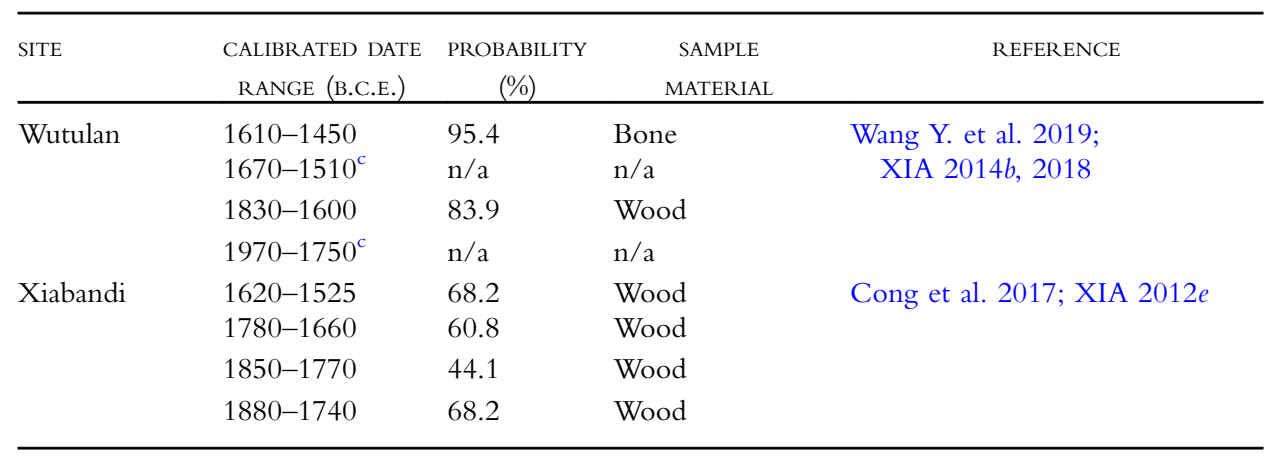

${ }^{\text {a }}$ Sample taken from pit fill of grave M3-3.

${ }^{\mathrm{b}}$ Only sample taken from burial in main building complex at Husita; the rest are from Harulu Cemetery.

${ }^{\mathrm{c}}$ Unpublished calibrated B.C.E.dates presented at the 2017 New Archaeological Discoveries in Xinjiang

Project Briefing 2017 年度新疆考古新發現報告會 in Urumqi (XIA 2018).

\section{Transliteration of Toponyms}

Throughout this article, we use toponyms transliterated in Chinese pinyin, followed by corresponding Chinese characters. Where available, Kazakh, Uyghur, or Mongolian place names are provided in parentheses. In some cases, the toponyms have been transliterated several times by local populations or through an official system of nomenclature, which makes it difficult to trace the original ethnic-linguistic designation of the word. For example, some present-day Mongol toponyms in Bortola were once Kazakh place names. For well-known geographical names, whichever spelling is most commonly used in scholarly literature may be used to facilitate comprehension (e.g., Alatau for Alatao). See Appendix A for list of toponyms and their variants.

\section{PHYSICAL ENVIRONMENT AND SUBSISTENCE ECONOMIES OF BORTALA AND ILI RIVER VALLEYS TODAY}

The Tian Shan range traverses the entire width of Xinjiang Uyghur Autonomous Region (Fig. 1, Fig. 2). They constitute a natural divide separating the modern administrative area into northern and southern Xinjiang (colloquially known as Beijiang 北疆 and Nanjiang 南疆). The western mountain ranges split into two chains. The northern chain includes the Yilianhabi'erga 依連哈比爾尔 and Boluokenu 博羅 科努 (Borohoro) Mountains and stretches into eastern Kazakhstan, while the southern chain, including the E'erbin 額爾賓, Huola 霍拉, and Ha'erketawu 哈爾克他烏 ranges, runs southwest along the border of China into Kyrgyzstan.

\section{Bortala River Valley}

Bortala River Valley originates in the Hongbielin 洪別林 mountain pass (3235 masl) at the intersection of Borohoro's Biezhentao 別真套 (Begijentao) mountain range and the Dzungarian Alatau, which is coterminous with the China-Kazakhstan border. The 
Bortala Valley area spans $79^{\circ} 53^{\prime}-82^{\circ} 53^{\prime} \mathrm{EW}$ and $44^{\circ} 02^{\prime}-45^{\circ} 23^{\prime} \mathrm{NS}$ and falls under the jurisdiction of Wenquan 溫泉 County. It is bound to the north by Dzungarian Alatau, with ridge lines at 3000 masl, and to the south by the western Tian Shan ranges, with ridge lines between 3500 and 4500 masl (Chen et al. 2007:1). The funnel-shaped topography delineates a natural border that delimits the extent and movement of material cultures traversing the Tian Shan and Dzungarian Alatau.

Bortala River flows eastward, with inflows from multiple tributaries originating in the mountains, and culminates in a drainage basin that covers an area of $15,946 \mathrm{~km}^{2}$ (Chen et al. 2007:3). It travels a course of $252 \mathrm{~km}$ into the endorheic salt lake of Aibi 艾比 (Ebi) in Dzungarian Basin (Chen et al. 2007:1, 3).

Flanked on three sides by high mountains, Bortala River Valley experiences a continental climate with pronounced seasonality. The average temperature in summer is $22^{\circ} \mathrm{C}$ and rainfall ranges between $53 \mathrm{~mm}$ and $238.2 \mathrm{~mm}$. Precipitation is the highest between the months of May and August when flash floods are common (Chen et al. 2007:1, 2, 5). Bortala Valley lies in an arid zone with an average precipitation per annum of less than $350 \mathrm{~mm}$ in the mountains and less than $200 \mathrm{~mm}$ in the valleys (Chen et al. 2007; Cong and Jia 2019:221). The average temperature is $-15.7^{\circ} \mathrm{C}$ in the coldest month of January (Chen et al. 2007:1-2).

The valley formed as a result of the recession of Quaternary glacial landforms, which over time deposited masses of erratics on piedmont slopes. These deposits have provided copious raw materials for stone construction in the area. Streams carry eroded debris downslope, carving gullies and forming alluvial fans. In the warmer months, the thawing of ice and higher precipitation generate flash floods on alluvial plains where large tributaries join the main river course. The small rivers are iced over for roughly six months of the year from late October to late April.

From the upper to the lower reaches of the river, the river basin can be divided into six vegetation zones, namely the alpine meadow zone, subalpine meadow and steppe zone, forest-shrub zone, shrub steppe zone, desert steppe zone, and desert zone (Li et al. 2014:1519). The predominant types of vegetation are meadow and droughtresistant deciduous flowering shrubs, tufted grass, and low-growing trees and coniferous trees. The main type of grass is the drought and salt-resistant yellow bluestem 白羊草 (Bothriochloa ischaemum). Picea and Betula are the most common tree genera; the latter covers up to 70 percent of the land delineated as Nature Conservation Area ( $\mathrm{Li}$ et al. 2014:1519). The percentage of vegetation cover varies. Between 3000 and 3500 masl, it is less than 10 percent (Wenquan 2003:96). Between 2900 and 1500 masl, it increases to 35 percent, although coverage can reach 65-75 percent, particularly in areas with forest vegetation. Spruce (Picea asperata) is a common forest species found in ravines and on north-facing slopes (Wenquan 2003:95). Willow, elm, and sea buckthorn shrub are popular species found along the river banks and flood plains below 1200 masl, where vegetation cover varies between 50 and 80 percent. The middle reaches of the Bortala River courses through wetlands where fields of wheat (Triticum spp.), sunflower (Helianthus annuus), corn (Zea mays), potato (Solanum tuberosum), and beetroot (Beta vulgaris) are cultivated today. Bortala River Basin is pedologically characterized by gray and gray-brown desert soils, salinized soils, meadow soils, and marsh (Wenquan 2003:95). Loess deposits are found only in the lower river valley on arable alluvial fans.

Apart from agriculture in the wetlands and flood plains, pastoralism constitutes a significant sector of the local economy today. A district survey recorded 6,190,000 
acres of pasture over a decade ago (Wenquan 2003:93). The main herding areas are on piedmont floors on either side of the upper and middle reaches of Bortala River and on the banks of Lake Sailimu 賽里木 (Sayram) at the foothills of Tian Shan (Chan 2017b:545). Seasonal transhumance of livestock composed of sheep, goats, cattle, horses, or Bactrian camels is generally carried out over three locales, with separate encampments for winter, summer, spring, and autumn (Cong and Jia 2019:221). Many of the predominantly Kazakh and Mongol pastoralist households have relocated to nearby townships and cities following the implementation of state-instituted sedentarization and urbanization measures in the past decade. Consequently, herding is contracted out to a small number of the remaining households that have been commissioned by the state to monitor pasture use and tend livestock (Chan $2017 b: 547)$.

\section{Ili River Valley}

Boluokenu Range marks the northern edge of Ili River Valley and separates it from Bortala Valley. Nalati Range constitutes the southern border; its eastern end stretches northeast toward the Boluokenu mountains and connects to Ha'erketawu 哈爾克他烏 Range in the west. Ili Valley begins at the origin of Gongnaisi 恐乃斯 River at the Dundeguole 敦德郭勒 mountain pass $\left(43^{\circ} 12^{\prime} 10.1^{\prime \prime} \mathrm{N}, 85^{\circ} 34^{\prime} 46.7^{\prime \prime} \mathrm{E}\right)$ in Hejing 和靜 County. It is partitioned longitudinally by multiple Tian Shan ranges running almost parallel to its main water courses. The middle of the valley is the intersection of a few topographic features. Running east-northeast, the Wusun 烏孫 Range separates the counties of Gongliu 鞏留 (Toqquztara) and Xinyuan 新源 (Künas) from Tekesi 特克斯 (Tekes) and Zhaosu 昭蘇 (Mongolküre).

Immediately east of Wusun Range, Tekesi (Tekes) River 特克斯, the largest tributary of Ili River, travels north to meet Gongnaisi River and Kashi (Kax) 喀什 River flowing from the northeast. These three tributaries merge into Ili River, which flows westward out of China and ultimately into Lake Balkhash in Kazakhstan. Awulale 阿吾拉勒 Range lies between the Kashi and Gongnaisi rivers. The drainage basin for the Ili River Valley within Xinjiang measures $56,000 \mathrm{~km}^{2}$ and includes these major tributaries and around 150 lower order streams (Luan et al. 2017:211; Zhao et al. 2009:2047).

The orography of Ili Valley gives shape to its three tributary valleys, each of which can be distinguished by three concentrations of archaeological sites in Nileke county, Gongnai and Xinyuan counties, and Zhaosu and Tekesi counties. The region experiences a temperate continental climate with an average temperature of $10.4^{\circ} \mathrm{C}$, but an inversion layer covers the north-facing slopes at 1000-3000 masl for 4 to 5 months of the year where the temperature increases by 3 to $5^{\circ} \mathrm{C}$ every 1000 masl. Precipitation is also higher in the mountains than on the plains. Under the influence of a wet westerly, the annual precipitation can exceed $800 \mathrm{~mm}$ in some areas (1500-2500 masl) (Luan et al. 2017:212). This is almost four times the precipitation at the capital city of Yining 伊寧 (Ghulja), which at 663 masl receives an average annual rainfall of around $250 \mathrm{~mm}$. The most expansive winter pastures in the area today (e.g., at Bayinbuluke 巴音布魯克 [Bayanbulak]) are located above 2000 masl.

The high Ili valley (2800-2100 masl) is covered by lush montane vegetation, predominately expansive high-altitude grasslands and pine forests. There is a large concentration of early archaeological sites in the foothills and first and second river terraces between 1800 and 1200 masl. Broad-leafed trees grow here on loess-rich, 
arable soil, mainly chernozem, sierozem, and chestnut (Zhao et al. 2009:2047). Chernozem is a fertile black soil particularly suitable for agriculture. Many of the sites are found where there are high concentrations of chernozem in the Kashi river valley and along Tekes River. With a large drainage basin and orographic precipitation, Ili has been a center of development of agricultural lands ever since the Qing Dynasty, when the Tuntian system was revived by resettling military troops to reclaim farmland (a function similarly fulfilled today by the Bingtuan 兵團 or Production and Construction Corps).

$$
\begin{aligned}
& \text { ARCHAEOLOGICAL SURVEY OF BORTALA RIVER VALLEY (2OI2-2OI6) AND } \\
& \text { EXCAVATIONS AT ADUUCHULUU (2OI I-2OI7) AND HUSITA (2OI6-2OI9) }
\end{aligned}
$$

According to unpublished reports from the Third National Cultural Relics Census Archaeological Survey, over 10,000 structures in 214 sites (defined as archaeological sites) have been documented in Bortala River Valley in an area measuring $4500 \mathrm{~km}^{2}$ (Fig. 1). Small-scale maps and descriptions of the individual locations of 213 sites were presented in two internal publications commissioned by the Bortala Prefecture Bureau of Cultural Relics Management, Bureau of Cultural Relics of Wenquan County, and Xinjiang Uyghur Autonomous Region Bureau of Cultural Relics (Xinjiang Cultural Bureau 2011 a 2011b). Intensive surveys and excavations conducted between 2011 and 2019 by the Institute of Archaeology at the Chinese Academy of Social Sciences (henceforth, IA-CASS) provided more data, particularly on a previously unknown site, Heishantou. The data presented in this article were collected during the authors' participation in the IA-CASS project.

The majority of the sites in the area were found between altitudes of 1000 and 2000 masl. To be precise, there are 171 sites (79.9\%) and 8047 structures (77.79\%) in the 1000-2000 masl range, where piedmont floors and river terraces are located. Many of these sites are scattered along the primary north-south flowing tributaries of Bortala River. There is a sharp decrease in the number of sites and structures above 2000 masl to about a third of those found at lower altitudes (i.e., 43 sites and 2298 structures).

The IA-CASS expedition selected 16 locations from the national census survey (Xinjiang Cultural Bureau 2011a, 2011b) for intensive site survey between 2012 and 2016 (see Figure 3 for representative structures at these sites). The sites were chosen based on two criteria: (1) the presence of large concentrations of diverse structure types in a confined area; and (2) Bronze Age or early Iron Age surface architectural forms (Bourgeois et al. 2014; Caspari, Plets et al. 2017). The objective was to trace temporal and spatial changes in the form, use, and layout of stone structures within a topographically definable space. To date, ten of these locations have been mapped with satellite positioning devices, including handheld GPS and Real Time Kinematic (RTK) (error margin $\pm 1 \mathrm{~cm}$ ), and documented using drone photography (Chan 2017a).

Of these ten sites, Aduuchuluu (1971-2124 masl) and Husita (1489 masl) have been excavated between 2011 and 2019. ${ }^{1}$ Individual structures were photographed by aerial pole and drone photography for 3D reconstruction (Chan 2017a; Plets et al. 2012). The collected spatial data were visualized using ArcGIS and Agisoft PhotoScan. Structural and material finds were recorded with a total station (using a geodetic coordinate system) and RTK. 
A total of 23 Accelerator Mass Spectrometry (AMS) radiocarbon dates have been produced for Aduuchuluu (ADCL) (Table 2); ten of them are unpublished dates from the second excavation site at Aduuchuluu, ADCL II. Dates for several burials at Husita have also recently been published (Jia X. 2019). While we discuss excavation results from both sites in this article, our focus is on Aduuchuluu because of the availability of comprehensive data from seven years of fieldwork between 2011 and 2017.

\section{HABITATION STRUCTURES}

\section{ADCL I and ADCL II: Results of Excavations (2011-2017)}

Aduuchuluu (Adunqiaolu 阿敦喬魯) is situated on piedmont floors in the upper river valley approximately $8 \mathrm{~km}$ north of Bortala River and south of the Chaganwusu mountain pass in the Dzungarian Alatau at ca. 2200 masl. Traversing this area is a tributary of the Bortala River that connects to another river that flows northwest into Lake Balkhash in Kazakhstan. Aduuchuluu is at present a winter pasture used for collective herding in compliance with state-instituted grazing bans (Chan 2017b). A number of permanent pastoral residences have been set up in the recent years as herding bases and there are also a few seasonal encampments.

The site was first documented in 1988 during an archaeological survey conducted by the Bortala Prefectural Museum (Xinjiang Museum 1995:595). The surveyors found stone mounds, circles, anthropomorphic statues, and petroglyphs depicting figures of ruminants, humans, and other wild animals (Li and Lü 2003:21). It was listed in 1999 as a protected archaeological site (wenwu baohu danwei 文物保護單位) by the decree of the Chinese National Cultural Heritage Protection Law (Zhongguo Renmin Gongheguo Wenwu Baohufa 中華人民共和國文物保護法) (Li and Lü 2003:20).

Excavations carried out between 2011 and 2017 centered on four investigative areas containing multiple clusters of structures (Chan 2017a; Cong 2016; IA CASS et al. 2013; Jia, Betts, Cong et al. 2017). The clusters constitute two sites, coded ADCL I and ADCL II, each of which consists of a habitation zone and a burial zone (Fig. 4). ADCL I is at a lower altitude than ADCL II situated ca. $800 \mathrm{~m}$ southeast. The habitation zones of ADCL I and ADCL II measure approximately $8 \mathrm{~km}^{2}$ (Fig. 5) and $3 \mathrm{~km}^{2}$ (Fig. 7 top), respectively. The ADCL I cemetery covers a $0.06 \mathrm{~km}^{2}$ area (Fig. 6) and the ADCL II cemetery measures $484 \mathrm{~m}^{2}$ (Fig. 7 bottom).

Situated in a modern-day winter pasture on a leeward south-facing slope, the habitation area of ADCL I comprises three interconnected structures numbered F1, F2, and F3 (Fig. 4). "F" stands for fangzhi 房址, meaning “residential/habitation site.," This structural conglomerate is laid out on a ca. 30 degree slope on a northeastsouthwest descent. Eight similar structures (F4-F11) have been found in the vicinity.

ADCL II includes two habitation structures, also coded F1 and F2 (Fig. 3, Fig. 7 top).

ADCL I-F1 is a symmetrical subterranean quadrangular structure with the dimensions of $22 \times 18 \mathrm{~m}$ (Fig. 5). Of all the fangzhi structures at ADCL, it is the most architecturally striking and structurally complex. Its perimeter is made up of two parallel rows of stone slab walls spaced from $0.98 \mathrm{~m}$ to $1.33 \mathrm{~m}$ apart (IA CASS et al. 2013:26). This was likely to have been a single rammed earth wall reinforced by stone slabs on either side (Cong and Jia 2019). Within the enclosure, there are various stone arrangements forming rows, clusters, pits, circles, and quarter circles. The entrance 


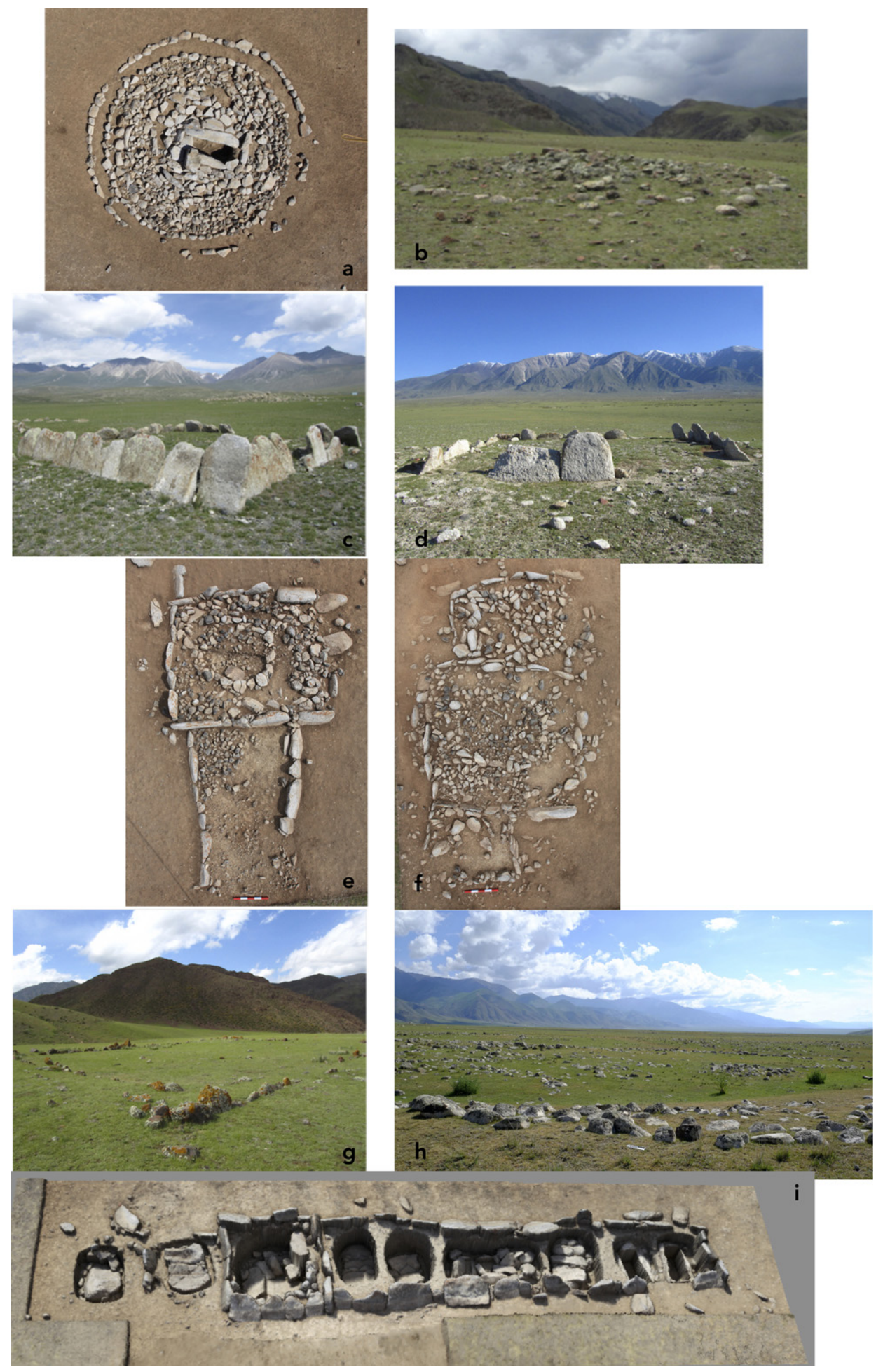

Fig. 3. Examples of different structural types in Bortala River Valley: (a) M88 round cairn with center slab grave, ADCL I Cemetery; (b) round cairn structure, Etuokesai' er Turigen; (c) SM9 pre-excavation, ADCL I Cemetery; (d) slab grave structure, Hala'ou; (e) SM29-30 mid-excavation, slab grave aggregates; (f) SM23-24-25 mid-excavation, slab grave aggregates; (g) large quadrangular enclosure with double-stone slab perimeter, Etuokesai'er Turigen; (h) large stone building complex preexcavation, Husita; (i) SM36, chain slab grave, ADCL I Cemetery (photogrammetric reconstruction by Annie Chan) (photos a, e, f by Dexin Cong; all others by Annie Chan). 
midway along the southern perimeter is delineated by a double stone slab wallprotrusion orientated to the southeast. F1's north wall follows the outline of an antechamber that, located at the rear corners, gives the structure the shape of the Chinese character ao 凹.

ADCL I-F2 and F3 are connected to F1 at its north wall (Fig. 5). The stone wall components of F2 are poorly preserved; damage is apparent in the displacement of the stones. Despite its size (116.4 m E-W, 6.4-8.7 m N-S), only a few dispersed animal bone fragments, ceramic sherds, and chipped stone artifacts were found on the surface. No material remains were found in F3. No further scientific analysis of remains from these two enclosures has been carried out, but we note that their position on a leeward slope and structural relationship to F1 is similar to the arrangement of animal pens and ancillary living areas in pastoral dwellings of modern-day Bortala (Cong and Jia 2019).

It may be hypothesized from the ethnographic examples that ADCL I-F1 was the main domestic activity area. The architecture and excavated remains suggest that the enclosure comprises at least three structural/functional zones that were occupied intermittently at different times. A double stone wall separates the structure into halves along a central east-west axis. The northern half of the structure is further divided into two sections by another north-south wall.

A self-enclosed structure that was built during the first phase of occupation is located in the northwest quadrant of F1 (Fig. 5). It contained the highest concentration of animal remains (i.e., bones and teeth of equids, caprids, canids) and ceramic sherds within ADCL I-F1 (IA CASS et al. 2013:26; Jia, Betts, Cong et al. 2017). It measures $7.2 \mathrm{~m}$ by $6 \mathrm{~m}$, occupying at least a quarter of the surface area of ADCL I-F1. Its western and northern walls were later incorporated into the external wall of ADCL I-F1, but its eastern and southern walls are the originals. The base of the western walls is lined with stone slabs, on top of which small stones are stacked in multiple layers; the tallest part of the wall measures $1.2 \mathrm{~m}$. There appears to be a $0.85 \mathrm{~m}$ wide and $2.9 \mathrm{~m}$ long doorway toward the western end of the southern wall (Fig. 5 inset photo). In a later period, two child burials were installed, superimposed over the original chamber structure (Cong 2016).

The northeast quadrant is covered by an arrangement of stones that represent structural reuse or adaptation over multiple occupational periods. It appears that the stones were building materials (possibly reappropriated for a cairn) of a previously selfenclosed space that was originally the northeast chamber. Measuring $5.1 \times 5.3 \mathrm{~m}$, this chamber is slightly smaller than that of the northwest quadrant. It is enclosed by its own walls on the south and west sides, while sharing its northern and eastern walls with the larger ADCL I-F1 structure.

The western wall of the northeastern chamber runs alongside the eastern wall of the northwestern chamber, creating a partition space roughly $1.3 \mathrm{~m}$ wide and approximately $1 \mathrm{~m}$ tall at its highest. This space separates the two northern quadrants. The base of the wall is built of erect slabs, atop of which is some rudimentary stone masonry. A $0.9 \mathrm{~m}$ gap toward the western end of the southern wall might have been an entryway. Small chipped stone tools, ceramic fragments, and horse phalanges are found in this area.

Unlike the northern half of F1, the southern part lacks multiperiod structural features. There is an oval stone cluster in the southeastern part (ca. $5.2 \mathrm{~m}$ diam.) and quarter circles with double borders (ca. $4 \mathrm{~m}$ diam.) in the southeastern and the southwestern corners where a small number of animal bones (caprid astragali and 


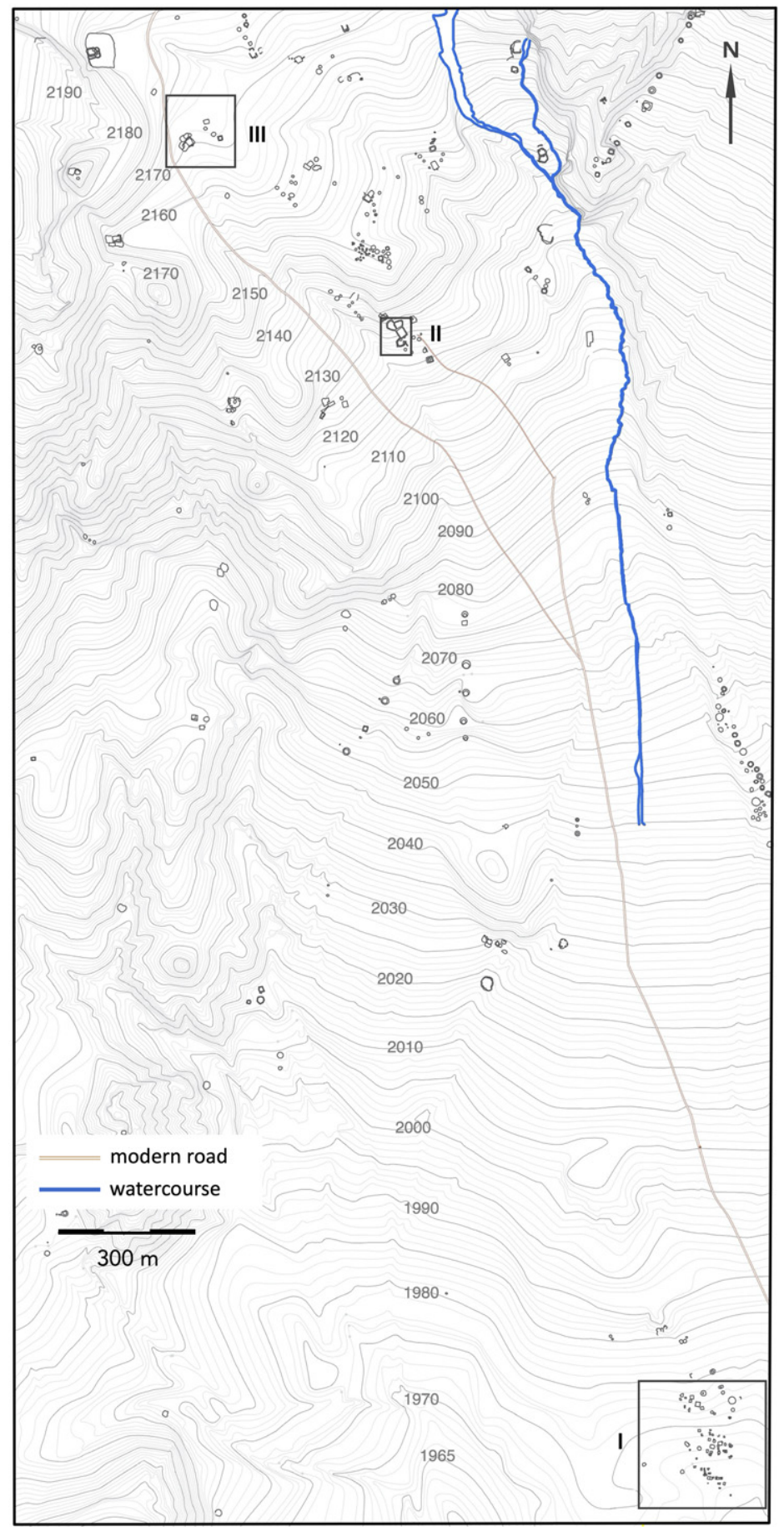

Fig. 4 Aduuchuluu area plan, showing: (I) ADCL I Cemetery; (II) ADCL I habitation site; (III) ADCL II habitation and burial sites (drawing by Changfeng Ding and Annie Chan). 


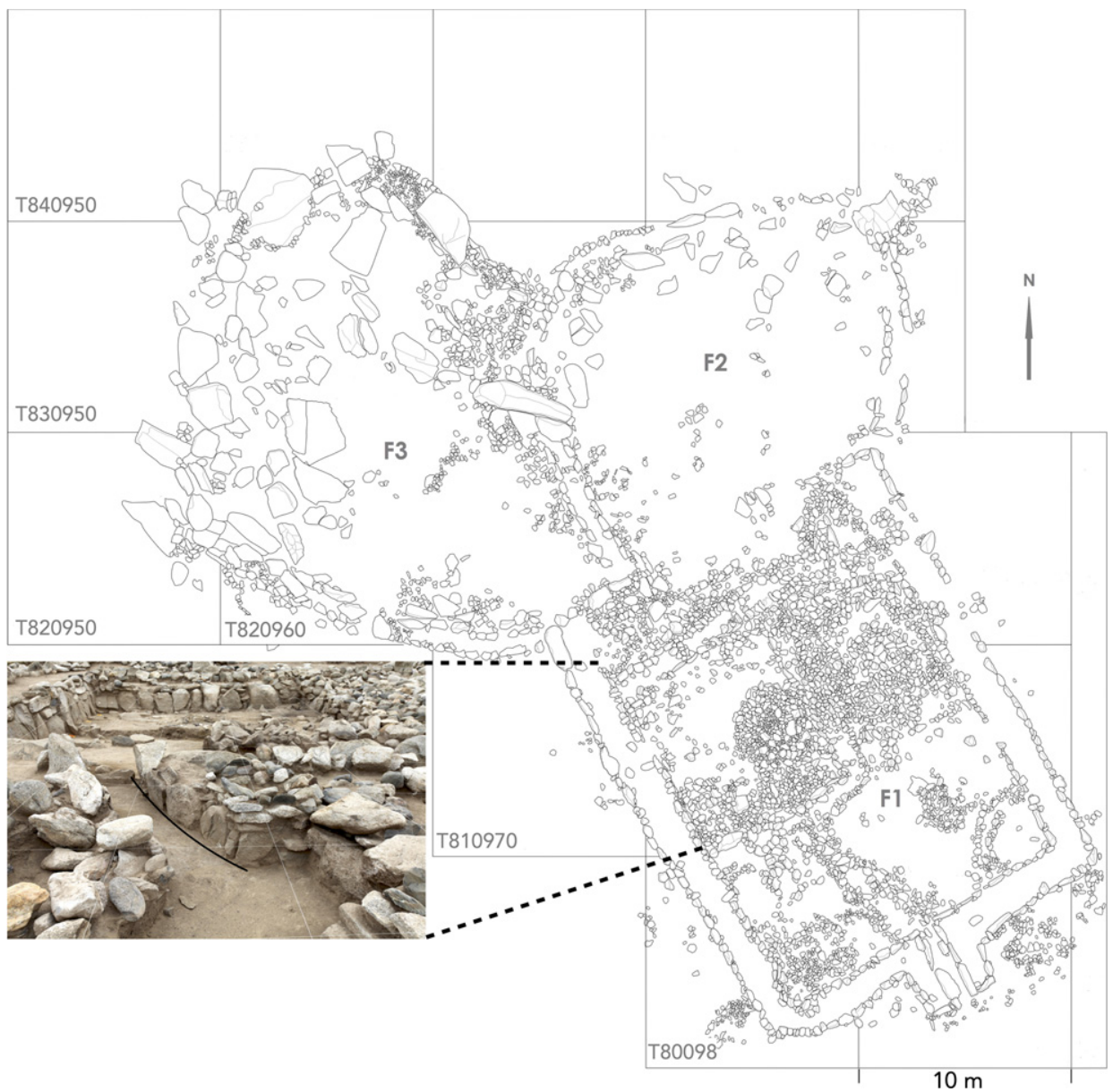

Fig. 5. ADCL I habitation area $(10 \times 10 \mathrm{~m}$ grid), showing F1, F2, and F3 plans post-2012 excavation (drawing by Changfeng Ding and Annie Chan); inset photograph NW quadrant of F1 (looking north), with black line marking entryway (photo by Dexin Cong).

fragmented long bones) and ceramic fragments were found (IA CASS et al. 2013:26). Furthermore, a round hearth $1 \mathrm{~m}$ in diameter is at the center of ADCL I-F1. Fragments of antlers of red deer (Cervus elaphus), bronzes, stone tools, and ceramics were found here (Cong 2016). The absence of postholes within ADCL I-F1, its quadrantal sections, and the distribution of material remains suggest the northern half of the structure contained separate roofed chambers, while the southern half was a courtyard area.

Two habitation structures with surface features similar to F1 were excavated at ADCL II. Both are aligned NS, with ADCL II-F1 in the north and ADCL II-F2 in the south. ADCL II-F1 measures $11.1 \mathrm{~m} \mathrm{E-W}$ and $11.4 \mathrm{~m} \mathrm{~N}-\mathrm{S}$ (Fig. 7 top). The northern wall of ADCL II-F1 is partly shared with the northern wall of ADCL II-F2, which is an elongated enclosure with dimensions of $116.4 \mathrm{~m} \mathrm{E-W}$ and $6.4-8.7 \mathrm{~m} \mathrm{~N}-\mathrm{S}$. The foundation stones of ADCL II-F1's northern, southern, and western walls are 


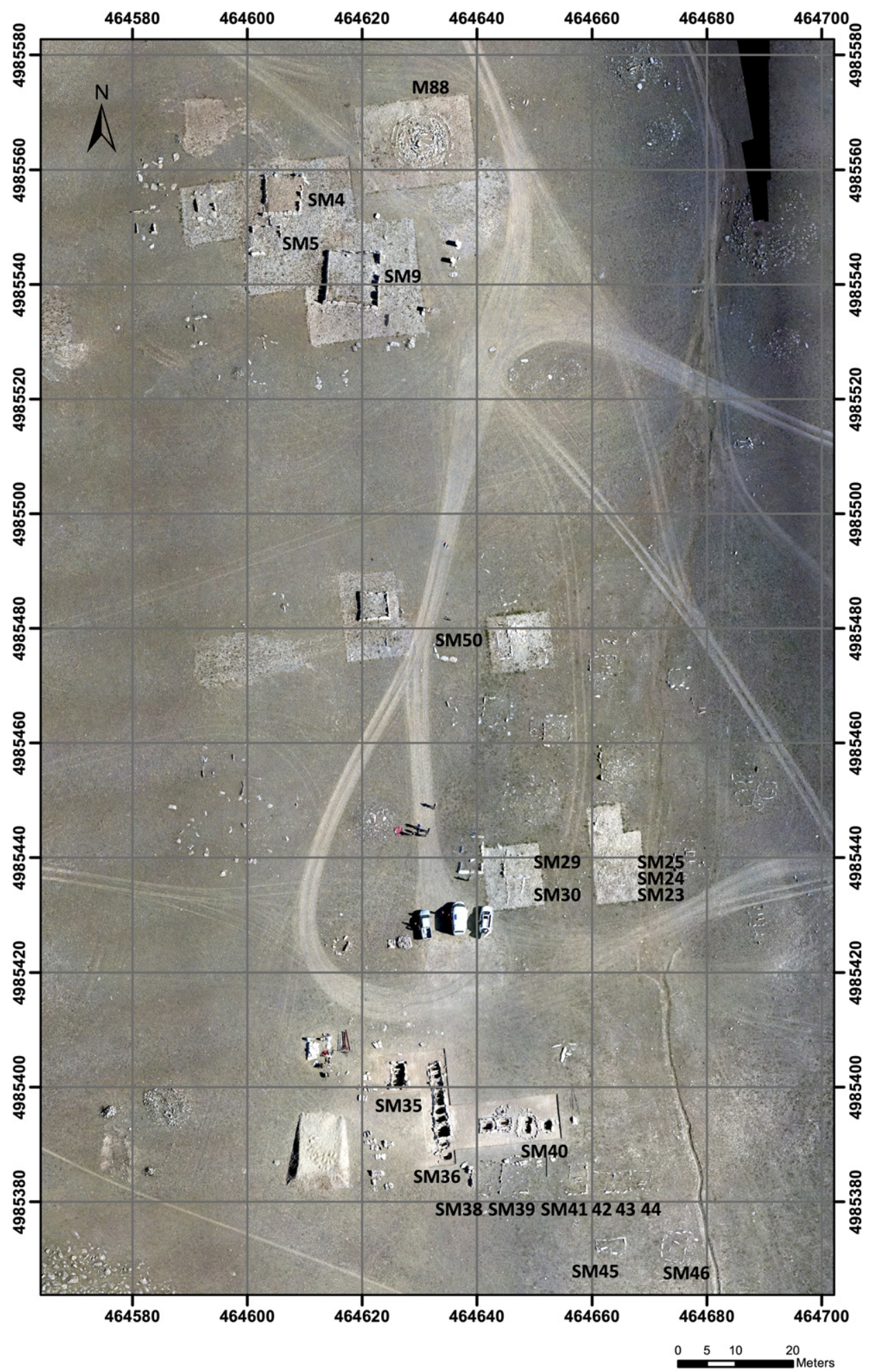

Fig. 6. Orthophoto showing layout of burial structures in ADCL I Cemetery (ca. $\left.0.06 \mathrm{~km}^{2}\right)$; each grid square is $20 \times 20 \mathrm{~m}$ (drone photography by Jianguo Liu; orthoimaging by Annie Chan). 

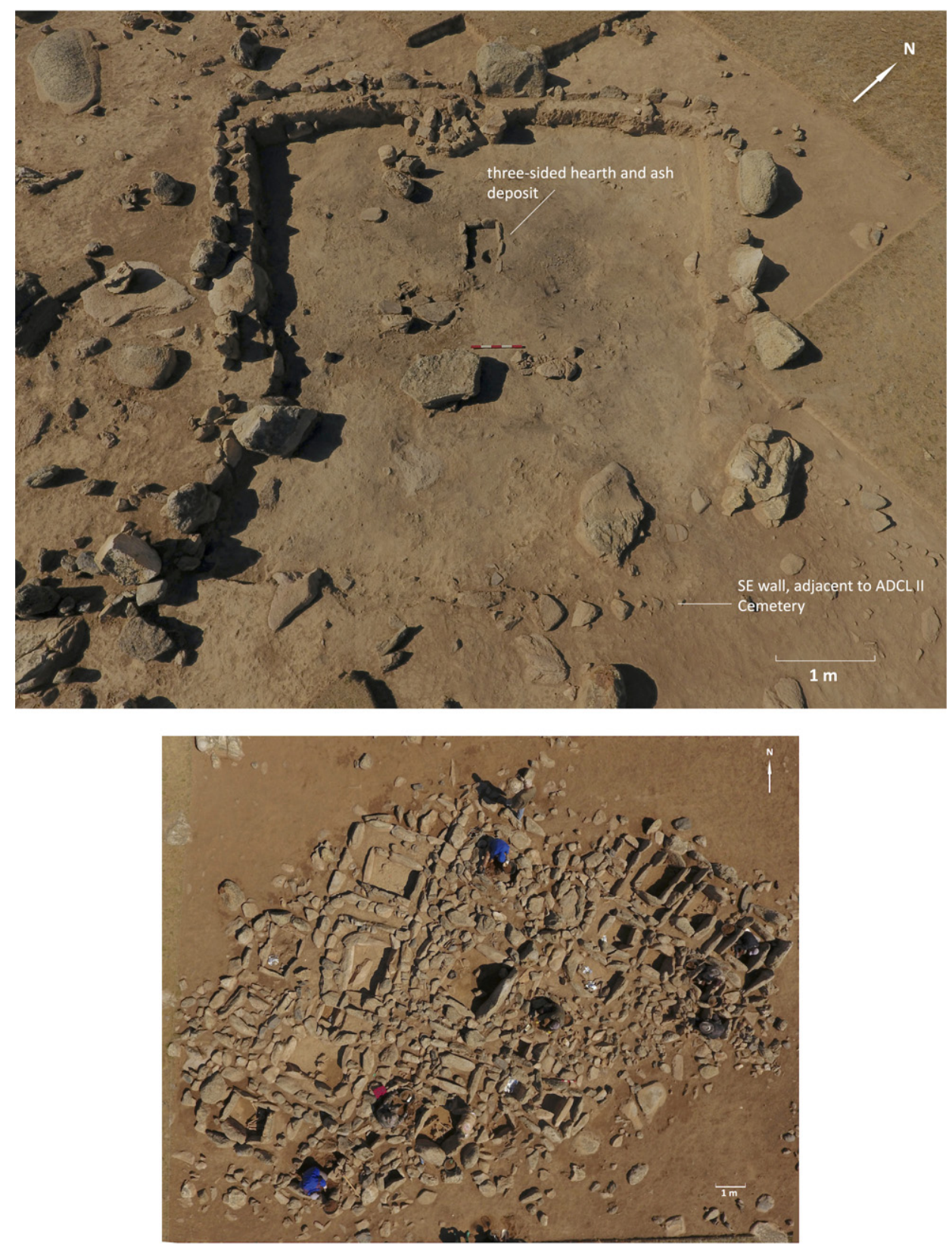

Fig. 7. View from above of ADCL II-F1 (top) and ADCL II Cemetery (bottom) (photos by Dexin Cong). 
preserved, but the eastern wall has been badly damaged. The stones of the wall measure between 50 and $60 \mathrm{~cm}$ wide. Slightly west from the center of ADCL II-F1 is a rectangular fireplace $1.49 \mathrm{~m}$ long $\times 0.68-0.9 \mathrm{~m}$ wide $\times 0.25 \mathrm{~m}$ deep; it is outlined by long, erect slabs on three sides. Ceramic fragments are concentrated on either side of the fireplace. A large ceramic vessel was found in a semicircular subterranean storage cellar roughly $1 \mathrm{~m}$ southeast of the fireplace.

Six AMS radiocarbon dates were obtained from ADCL I-F1 and one from ADCL II-F1. The results show that the structures were contemporaneous and in use between ca. 1750 B.C.E. and 1600 B.C.E. ADCL-F1 was likely abandoned after this time since a later burial (M1) superimposed on the southwestern corner is dated to the beginning of the sixteenth century B.C.E. (Table 2).

\section{Excavations at Husita in Middle Bortala Valley}

Since 2016, excavations at the site of Husita 呼斯塔 (Khustai), at 1489 masl in the middle of Bortala River Valley, have yielded findings of large multicomponent, nonburial structures (Fig. 1). The structures are spread out across the flood plain of Xiaohusita River and several of its tributaries at the foothills of Dzungarian Alatau, an area of nearly $12 \mathrm{~km}^{2}$. Seasonal floods are common; the area becomes inaccessible by road in the wet season. IA-CASS first surveyed the site in 2013, at which time 111 structures were mapped using RTK. Four groups of structures were identified, including (from north to south): a habitation structure composed of three connecting quadrangular enclosures atop a hill (120 m high) called Heishantou 黑山頭 (Jia 2019); a conglomerate of more than one hundred habitation and burial structures on the alluvial fan; a quadrangular enclosure connected to what looks like a low wall halfcircling the top of the Xiaohusita hill (just south of the flood plain); and, on an adjacent hill to the west, Harulu 哈如魯 Cemetery (Jia X. 2019) (Table 1).

The large conglomerate of structures on the alluvial fan has been the center of field investigations since 2016. Excavations revealed a building complex with an area of ca. $5000 \mathrm{~m}^{2}$ and comprising a main building, front and antechambers, courtyard, and walls (Jia X. 2019). The walls are made up of two stacked-stone walls with mixed soil filling the space between them. The outside wall is $1.3 \mathrm{~m}$ high and the inside wall is $0.8 \mathrm{~m}$ high. Human remains, ceramics vessels of gray or red-tempered ware with incised geometric patterns, and bronze objects (including an unusual dagger with an antler haft) were discovered in a ritual pit at the southwestern corner of the main building.

The structural remains on Heishantou 黑山頭 hill were also excavated. The building here is of the same form as the structures on the alluvial fan. Excavators found hearths enclosed with masonry walls on three sides, inside of which were ash and ceramic fragments of the same type of ceramic ware as that found in the complex on the alluvial fan. They also discovered two complete horse skulls.

The two wall-like structures on the hilltops on either end of the flood plain are positioned at great vantage points. The panorama each offers suggests they were likely used to demarcate territory, either as ritual landmarks or strategic lookouts. Archaeologists have previously described these hilltop architectural remains as fortified structures manned by garrisons (Jia et al. 2018; Jia X. 2019). However, field research to date has provided no direct evidence corroborating this theory. The altitude and location of the structures relative to the flood plain area only suggest that they were likely nonhabitational structures that made ideal lookout points or geographical 
TABle 2. Radiocarbon DATES OF SAMPles ObTAined FROM ADCL I AND II

\begin{tabular}{|c|c|c|c|c|c|c|}
\hline $\mathrm{LAB} \mathrm{ID}^{\mathrm{a}}$ & SAMPLE ID & SAMPLE ORIGIN & SAMPLE MATERIAL & ${ }^{14} \mathrm{C}$ DATES B.P. & CALIBRATED DATE RANGE B.C.E. & PROBABILITY (\%) \\
\hline XA19983 & XBWAIIF1 & ADCL II F1 & Human bone & $3355 \pm 30$ & $1740-1535$ & 95.4 \\
\hline XA19992 & XBWAIIM5 & ADCL II cemetery M5 & Human bone & $3120 \pm 30$ & $1451-1291$ & 95.4 \\
\hline XA19993 & XBWAIIM10 & ADCL II cemetery M10 & Human bone & $3010 \pm 30$ & $1386-1128$ & 95.5 \\
\hline XA19984 & XBWAIIM12 & ADCL II cemetery M12 & Wood charcoal & $3225 \pm 30$ & $1607-1429$ & 95.4 \\
\hline XA19994 & XBWAIIM13 & ADCL II cemetery M13 & Human bone & $3115 \pm 25$ & $1438-1299$ & 95.4 \\
\hline XA19995 & XBWAIIM14 & ADCL II cemetery M14 & Human bone & $3100 \pm 25$ & $1428-1293$ & 95.4 \\
\hline XA20005 & XBWAIIM16 & ADCL II cemetery M16 & Human bone & $3230 \pm 30$ & $1608-1432$ & 95.4 \\
\hline XA20006 & XBWAIIM20 & ADCL II cemetery M20 & Human bone & $3180 \pm 25$ & $1501-1415$ & 95.4 \\
\hline XA20007 & XBWAIIM33 & ADCL II cemetery M33 & Human bone & $3430 \pm 25$ & $1873-1661$ & 95.5 \\
\hline XA20008 & XBWAIIM34 & ADCL II cemetery M34 & Human bone & $3140 \pm 25$ & $1495-1308$ & 95.5 \\
\hline UBA-19168 & XBWAM1-1 & ADCL I F1-M1 & Human bone & $3253 \pm 27$ & $1605-1581$ & 68.2 \\
\hline UBA-19163 ${ }^{\mathrm{b}}$ & XBWAF1-layer 2 & ADCL I F1 & Wood charcoal & $3331 \pm 38$ & $1666-1604$ & 68.2 \\
\hline UBA-19164 ${ }^{\mathrm{b}}$ & XBWAF1-layer 3 & ADCL I F1 & Wood charcoal & $3270 \pm 27$ & $1606-1574$ & 68.2 \\
\hline UBA-19165 $5^{b}$ & XBWAF1-layer 4 & ADCL I F1 & Wood charcoal & $3403 \pm 28$ & $1743-1680$ & 68.2 \\
\hline XA-16899 & XBWAF1 & ADCL I F1 W perimeter surface & Wood charcoal & $3346 \pm 25$ & $1682-1614$ & 66.94 \\
\hline XA- $16900^{\mathrm{b}}$ & XBWAF1 & ADCL I F1 SW corner & Wood charcoal & $3320 \pm 34$ & $1639-1533$ & 66.14 \\
\hline UBA-21985 & XWASM4-2(1) & ADCL I cemetery SM4 & Wood & $3337 \pm 32$ & $1728-1720$ & 68.2 \\
\hline UBA-19167 b & XBWAM9-1 & ADCL I cemetery M9 cist & Wood & $3434 \pm 28$ & $1769-1690$ & 68.2 \\
\hline UBA-19166 ${ }^{\mathrm{b}}$ & XBWAM9-2 & ADCL I cemetery M9 cist & Wood & $3447 \pm 31$ & $1870-1846$ & 68.2 \\
\hline XA-17133 ${ }^{b}$ & XWASM41 north & ADCL I cemetery SM41 & Human burnt bone & $3330 \pm 30$ & $1661-1546$ & 66.07 \\
\hline XA-17134 ${ }^{\mathrm{b}}$ & XWASM43 & ADCL I cemetery SM43 & Human burnt bone & $3346 \pm 30$ & $1687-1612$ & 65.93 \\
\hline XA-17132 b & XWASM45-east-2 & ADCL I cemetery SM45 & Human burnt bone & $3260 \pm 30$ & $1607-1500$ & 66.63 \\
\hline UBA-21986 ${ }^{\mathrm{b}}$ & XWAM50-1-2 & ADCL I cemetery SM50 & Wood charcoal & $3266 \pm 34$ & $1607-1571$ & 68.2 \\
\hline
\end{tabular}

${ }^{a}$ UBA = 14CHRONO Centre for Climate, the Environment, and Chronology, School of Geography, Archaeology, and Palaeoecology, Queen's University of Belfast; $\mathrm{XA}=$ Institute of Earth Environment, Chinese Academy of Sciences, Xi'an.

bA = Institute of Earth Environne 
landmarks. It is not yet known whether they served logistical, ritual, or defensive purposes or were used for pasture zoning. It cannot be assumed that positioning a lowlying wall along the circumference of a conical hill was necessarily intended for defensive or military uses, nor can it be argued that fortifying hilltop lookout posts sitting on $20-30^{\circ}$ slopes was a necessary security measure. Rather, similar studies of prehistoric stone structure use and distribution in Mongolia have shown that structures of greater physical or ritual visibility often functioned as territorial markers and were used to direct subsequent site placement or routes of communication and migration (Allard and Erdenebaatar 2005; Fitzhugh 2009; Miyamoto 2016; Seitsonen et al. 2014). Further elaboration could be made on this point, but this is a subject for a separate article.

\section{Reported Excavations of Habitation Structures in Ili River Valley}

Two sites on the banks of Kashi 喀什 River, Qialege'er 恰勒格爾 and Jirentai 吉仁台, have contributed important data to the study of Bronze Age habitation structures in Tian Shan (Fig. 2). Qialege'er was excavated in 2013 and fieldwork has been ongoing at Jirentai since 2015. Qialege'er is located at the northern foothills of Borohoro Mountains. The Xinjiang Institute of Archaeology (XIA) team conducted salvage excavation on two subterranean dwelling structures; one measures $6 \times 4 \mathrm{~m}$, but the other is too poorly preserved to measure (XIA 2014a). Ceramic remains discovered at the site are characteristic of Bronze Age Andronovo gray-tempered ware and calibrated radiocarbon dates of animal bones date the site to 1620-1500 B.C.E. (Table 1).

Jirentai is located on the third river terrace north of Kashi River. The area is covered by loess deposit and is a hub of agro-pastoralism in Ili today. As at Qialage'er, and indeed for most archaeological field research projects in Xinjiang, excavation at Jirentai began as a salvage operation, as a reservoir being built there would flood the area. Jirentai is a large site comprising a primary area with habitation and burial structures, kilns (Fig. 8a-d), and a freestanding tower $1 \mathrm{~km}$ away (Wang Y. et al. 2019). The entire site covers an $80,000 \mathrm{~m}^{2}$ area. A total of 14 calibrated radiocarbon dates recently reported for the site range from 2631 to 1020 B.C.E., that is, from the Chalcolithic to the Iron Age (Wang Y. et al. 2019:135). Based on the architectural and material finds, excavators distinguished three phases of settlement during the Bronze Age at 1600-1400 B.C.E., ca. 1400-1200 B.C.E., and ca. 1200-1000 B.C.E.

Ranging from $100 \mathrm{~m}^{2}$ to $400 \mathrm{~m}^{2}$, the six large subterranean habitation structures are among the largest Bronze Age habitation structures so far discovered in Xinjiang. The foundations of the structures were built vertically into the slope and fortified with stacked stones on four sides and wooden posts along the interior perimeter (Wang et al. 2019:133-134). Postholes were installed in rows around a central three-sided hearth that connects on a center N/NW-S/SE axis with a stone lined doorway extending from the southern side of the building (Fig. 8a, b). ${ }^{3}$ The placement of the postholes suggests that the structures had a multipitched roof. Other features include ash pits, coal deposits, cellars, and foundation trenches. Animal bones (caprids, bovids, and equids), ceramics, and ground stone agricultural tools are found in large quantities. Lipid residues were found in ceramic vessels (Wang et al. 2019:137).

The size of dwellings decreased at Jirentai during the middle period, but their forms became more varied. The 31 excavated structures measure between 20 and $60 \mathrm{~m}^{2}$ in surface area. They each have either a round or quadrangular perimeter, are either 

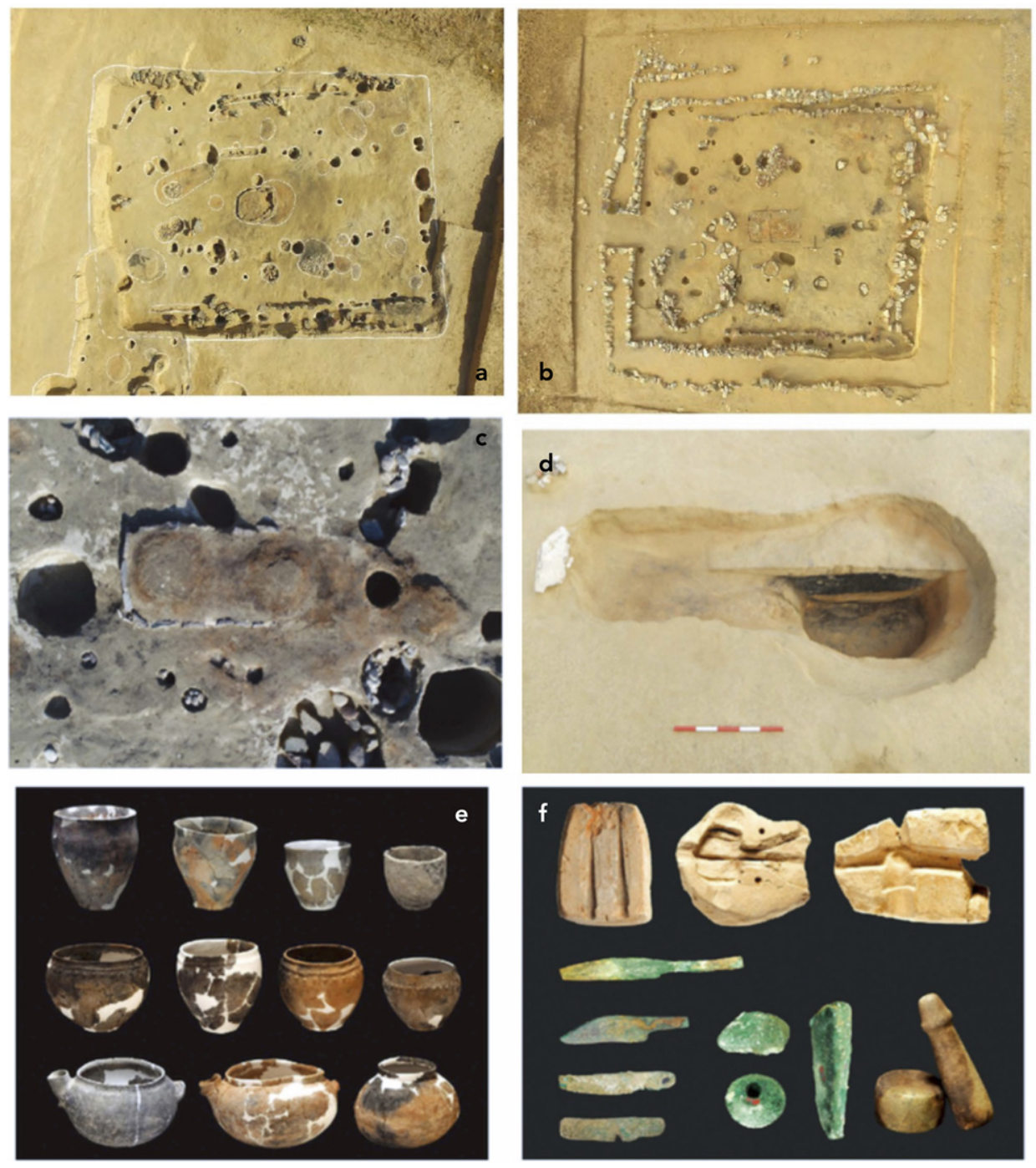

Fig. 8. Architectural and other material finds from Jirentai, Nileke County: (a) F2; (b) F6; (c) hearth feature in F25; (d) kiln Y4; (e) ceramic vessels; (f) ceramic molds and bronze and stone objects (not to scale) (after Wang Y. et al. 2019:134, pl. 5, pl. 6).

subterranean or above ground, and their entryways have different orientations (Wang et al. 2019:134). The shape of the hearths also changed; in this period, they are either round or multilateral rather than quadrilateral (Wang et al. 2019:134).

An important discovery at Jirentai is the earliest evidence of coal use in China. Large quantities of coal were found in multiple structures across the site; evidence of coal use has not been discovered at any other site in Ili or Bortala. In Jirentai's F2, one of the large dwellings, layers of coal blocks, cinder, and ash were discovered in large amounts in a corner, alongside ceramic molds for bronze mirrors and bronze awls (Wang and Ruan 2016; Wang Y. et al. 2019) (Fig. 8f). These finds prompted speculation that the 
structure was used as a bronze workshop, but evidence connecting coal use to bronze smelting activities at the site is lacking. No signs of smelting have been found in any of the six excavated kiln structures in which there are large amounts of coal. Only a small amount of slag and copper ore deposit was discovered in one of the smaller habitation structures, F23 (Wang Y. et al. 2019:134). Excavators posit that the prevalence of coal use at Jirentai may be explained by its proximity to several coal mines in the region (see also Wang L. et al. 2019).

Subterranean habitation structures have also been investigated at Qiongkeke (XIA 2002) and Kalasu (XIA et al. 2008) in Ili (Fig. 2). The Kalasu 卡拉蘇 structure covers an area of approximately $110 \mathrm{~m}^{2}$ and has a $4 \mathrm{~m}$ long, $0.8 \mathrm{~m}$ wide entryway with $0.2 \mathrm{~m}$ high threshold. The foundation of the structure is cut into a south-facing slope so that the northern walls $(1.2 \mathrm{~m})$ are higher than the southern walls $(0.4 \mathrm{~m})$ (XIA et al. 2008). It has 9 postholes, a hearth, and multiple round pits. The habitation structure at Qiongkeke 窮科克 also lies on a south-facing slope and is superimposed by Cemetery No. 1, an Iron Age burial structure (XIA 2002).

\section{BURIAL AND COMMEMORATIVE STRUCTURES}

\section{ADCL I and ADCL II Cemeteries}

ADCL I Cemetery is located on an even, gentle south-facing slope 1970-1980 masl. It comprises at least 66 burial structures, predominantly slab graves and cairns (Fig. 6). Of these, 28 were excavated between 2011 and 2016. ADCL II Cemetery is situated next to the habitation structures of ADCL II at 2165 masl. Another 34 slab graves were excavated there in 2017 (Fig. 7 bottom).

There are two primary structural forms found at surface level: low cairns with or without an outer circle, coded $\mathrm{M}$ for $m u$ 墓 (grave); and single or multiple adjoining slabbed quadrangular enclosures, coded SM for shiban-mu 石板墓 (slab grave). Earthen mounds are absent. The slabs are predominantly cut from two types of local lithic materials, granite and schist, but mostly granite.

Based on variations in structure and building components, the structures in ADCL I Cemetery can be divided into three cluster zones. The middle and southern clusters have a higher building density than the northern cluster; this is attributed to the greater number of burial features as well as higher degrees of connectivity between single burial units (Chan 2017a:125, 127). Seven radiocarbon dates were obtained from ADCL I Cemetery (Table 2). Figure 6 shows the location of burials from which samples were taken. The dates suggest that there were likely two periods of use, beginning in the northern cluster zone in the early nineteenth through early seventeenth centuries B.C.E., followed by the middle and southern zones in the early seventeenth through late sixteenth centuries B.C.E. The changes in grave architecture and funerary customs during this 400-year span are described as follows:

The northern zone comprises mostly single quadrangular structures enclosed by highly standardized, large, erect slabs; such slabs are absent from the other two zones. SM9, the largest and earliest individual slab structure in ADCL I (and in the entire Bortala River Valley), is a good example (Fig. 3c, Fig. 6). Measuring roughly $10 \times 10 \mathrm{~m}$, it is an equilateral structure enclosing two slab cists. The interior of the slab perimeter is buttressed by a stacked stone layer at its base. A complete child skeleton was found atop the cist. Only a small number of bones, along with remains of wood, 
were found inside the cist. The location of the child skeleton and other signs of disturbance at the pit opening suggest that this was likely a secondary burial.

SM 4 is a near-equilateral slab grave adjacent to SM 9; it is equipped with two burial chambers. The mouths of the pits are marked with stone circles at the surface. The northern pit contains cremated remains of a young adult and fragments of a ceramic vessel inside a cist. The southern chamber contains the burial of an adult male in the fetal position. The man would have been over $1.8 \mathrm{~m}$ tall; he is furnished with a pair of bronze earrings, a ceramic vessel, and a few caprid astragali. The capstones are plastered with a thick $(0.5 \mathrm{~cm})$ coat of fine yellow clay. A sample taken from the wooden cist in the southern chamber dates the structure to $3337 \pm 32$ B.P. $(1728-1720$ B.C.E.).

The middle and southern zones of the cemetery mostly consist of compound structures made up of multiple adjoining enclosures with perimeters composed of lowlying slabs and stones; they appear to have built rather haphazardly. These compound structures are typically made up of an initial enclosure to which proportionally smaller or narrower annexes were later appended. For example, SM23, SM24, and SM25 in the middle zone are three adjoining enclosures connected by two slab walls, with SM24 as the first enclosure to which SM23 and SM25 were later added (Fig. 3f, Fig. 5). The enclosure from which a wall is borrowed generally has longer sides than the enclosure for which the earlier wall has been adapted.

The chain burial of SM36, also in the middle zone, comprises 9 enclosures arranged linearly and 11 graves (Fig. 3i). It shows that the burial form can vary within a single structural aggregate. Each of the enclosures contains a single cist grave except for N3 (fourth from the north), which has three connecting cists. There are two primary burials $(\mathrm{N} 4, \mathrm{~S} 1)$, three secondary burials (N5, N6, S2), three cremations (N1, N3, S2), and a primary child burial (N2). The initial and center grave (third from the south) is likely the largest enclosure. Later enclosures are narrower and their slab cists are smaller (Fig. 3i).

SM35, adjacent to SM36, also exhibits a planned sequence of grave construction. The stratigraphical profile of the pits suggests that the southern and largest grave (SM35-1) was the first one to be built at the same time as the enclosure wall was being constructed. SM35-2 (in the middle) was installed afterward, with its pit cutting into SM35-1. The northern grave (SM35-3) was constructed last. The first grave contains a human burial accompanied by the fragmented skull of another individual. The middle and northern graves were likely looted; their capstones have been destroyed and partially removed and material finds are scarce. The middle grave contains a small amount of burnt bone fragments. The northern grave has burnt bones as well as a complete ceramic vessel.

SM38-44 are burials in an east-west-oriented single row in the southern zone. There are signs of extensive postdepositional disturbance. The capstones are missing from SM41 and SM44, both of which contain scattered burnt bones. Part of SM42's capstone was lifted off and then erected at the western end of the burial pit; the other half was still in place on top of the grave. The capstone of SM43 was shifted to the side of the burial pit, but a ceramic vessel was still in situ. The burial pits of SM42 and SM43 are reinforced by stone masonry walls built $(30-40 \mathrm{~cm}$ high) up from the level of the capstone. The structural configuration of these enclosures suggests that SM41 and SM43 were annexed to SM42 and SM44, respectively.

Immediately south of SM38-44 are SM45 and SM46. SM45 is made up of two connecting enclosures, with one cist in the western enclosure and two in the eastern enclosure. SM46 has two exposed adjoining cists that have been quite badly destroyed. 
To the immediate east of SM45 are two small circular enclosures, within one of which children's bones were found. A complete set of human remains, ceramic vessels, and small bronze objects have been recovered from SM41-46. The ceramic vessels have an etched dotted design on their base similar to the pottery of the Okunevo and Chermuchek (Ke'ermuqi) cultures (Kovalev 2005; Kubarev 2009; Shao 2008; Wang M. 2013; Wang and Qi 1995; XIA 1981).

M88 is one of the few cairns found at ADCL I (Fig. 6). It measures ca. $18 \mathrm{~m}$ in diameter and is composed of small pebbled pavements and cobbles of various sizes arranged in concentric circles. The capstone of the center cist has been displaced and the contents of the burial looted. Only a few pieces of human bone were found.

Like ADCL I, the burial structures at ADCL II can be grouped into 3 sections, but here the enclosures are interlinked on all sides, with cobbles filling the spaces between them (Fig. 7 bottom). The layout suggests that the construction might have begun with M16, at the center of the cemetery, and proceeded along a north-south axis. The cists measure between $0.93 \mathrm{~m} \times 0.63 \mathrm{~m}$ and $2.1 \mathrm{~m} \times 1.56 \mathrm{~m}$ and are rimmed by one or two rectangular slab borders. Radiocarbon dating of human bones and wood charcoal from the site gives a date range of between 1873 and 1128 B.C.E. Three phases of construction may be distinguished: ca. 1870-1650 B.C.E.; ca. 1610-1450 B.C.E.; and ca. 1450-1150 B.C.E. (Table 2).

ADCL II Cemetery has been quite badly disturbed and looted; human remains and ceramic fragments are scattered on the surface near the graves. Except for a few wellpreserved cists, most are missing their capstones and some of the cist slabs have already been exposed on the surface. Most of the burials are oriented east-west, but a few are aligned north-south. There are a total of six child/infant burials; the bodies are placed in the fetal position with knees slightly bent. One of the burials contains two crania. A complete set of adult human remains was discovered in M1.

Most of the material finds are discovered in graves that are structurally better preserved; these include bronze objects such as "buttons" (round, flat discs with looped stems) and needles as well as ceramic vessels, mostly of tempered brown clay and a few of red clay. Most of the vessels are flat bottomed jars and bowls, with the widest diameter at the shoulders, which are decorated with triangular or net patterns. Some have rims decorated with round nodules (rudingwen 乳丁紋). There are also roundbottomed vessels characteristic of Iron Age Karasuk Culture pottery. All surface ceramic finds have a red slip.

\section{Funerary and Commemorative Structures in Ili River Valley}

The structures in Ili River Valley total 142 assemblages (see Fig. 2 for locations of sites discussed below). They occur in two main forms: earthen mounds and stone mounds; some of the stone mounds appear with anthropomorphic stela (Wang and Qi 1995; Zhang et al. 2012). The majority of the assemblages have been identified as funerary or commemorative structures. The following is a synthesis of data gathered from published excavation reports, the authors' site visits, and personal communications with lead excavators.

Earthen mounds are characterized by raised earthen heaps under vegetation cover. Some are enclosed by an outer stone circle and some are overlaid with a layer of stones. The earthen mounds are usually arranged in a chain oriented north-south, as is seen at Tangbalesayi 湯巴勒薩依 (XIA 2012a). Their subsurface structures are vertical earthen pits (e.g., at Tangbalesayi) (XIA 2012a, 2012b) that may hold a cist (e.g., at 
Jirentai) (Wang and Ruan 2016, Wang Y. et al. 2019; XIA 2017), stone-lined chamber (e.g., at Tekesi) (XIA 2012c), or wooden coffin in a side chamber (e.g., at Tekesi) (XIA 2012c). Results of excavation show that earthen mounds in the Ili area can generally be dated to the Bronze Age. The 17 earthen mounds excavated at Wutulan contain trumpet-shaped bronze earrings and flat-bottomed, footed-based, urn-shaped, tempered gray ware (XIA 2014b). Such artefacts are characteristic of Andronovo Culture (Ruan 2013; Rudkovsky 2013; Shao 2009). At Kuokesuxi 闊克蘇西 Cemetery no. 2, seven Bronze Age earthen mounds $(8-20 \mathrm{~m}$ in diameter) were excavated from a cluster of over 200 burial structures (dated to different time periods) in an area measuring $19 \mathrm{~km}$ E-W and $16 \mathrm{~km} \mathrm{N-S} \mathrm{(Ruan} \mathrm{2012,} \mathrm{2013;} \mathrm{XIA} \mathrm{2012b).} \mathrm{All}$ nine Bronze Age burials excavated at Jirentai feature human remains in the fetal position; a few flat-bottomed ceramic vessels, a bronze mirror with a handle, and bronze earrings were also found (Wang and Ruan 2016; Wang Y. et al. 2019).

Stone mounds are more widely distributed than earthen mounds and are ubiquitous throughout western and northern Xinjiang (Chen 2017:513-524; Liu and Guan 2002; Zhang 1989; Zhang et al. 2012). They are found in Ili River Valley along Kashi, Gongnaisi, and Tekesi rivers. Most of these mounds have a circular horizontal profile, averaging 5-10 $\mathrm{m}$ in diameter; some have an outer concentric stone circle. Their height varies, but most of them are approximately $1 \mathrm{~m}$ high. Up to four pit burials may be found under a single mound. Burial goods attributed to the Iron Age of Xinjiang and the Karasuk and Scythian cultures, including iron arrowheads, ceramic vessels with rounded bottoms, and other bronze ornaments, have been discovered in such burials at Ayousai, Kuokesuxi, Qiongkeke, and Wutulan (XIA 2002, 2012b, 2013, 2014b). Stone mounds are a common type of funerary architecture that can be attributed to different archaeological cultures as early as the early first millennium B.C.E. or as late as the Turkic period (fifth to tenth centuries C.E.); they are difficult to date by surface features alone.

Stone and earthen mounds are often found together in the same clusters, with groups of more than 50 mounds common in Ili Valley. The largest clusters are along Kashi River in Nileke County at the sites of Ayousai 阿尤賽, Qiongkeke 窮科克, Tangbalesayi 湯巴勒薩伊, and Wutulan 烏土蘭. The Ayousai site has over 300 structures, including five large earthen mounds (XIA 2013). At Tangbalesayi, over 30 earthen mounds and cairns are distributed between 10 and $30 \mathrm{~m}$ apart in multiple north-south-oriented chains. Twenty-six graves were excavated in 2010. The lowlying earthen mounds measure $5-10 \mathrm{~m}$ in diameter, whereas the stone mounds (described as earthen mounds overlaid with cobbles) range from 10 to $20 \mathrm{~m}$ in diameter and 0.4 to $1 \mathrm{~m}$ in height (XIA 2012a).

\section{DISCUSSION}

Over the past decade, there has been an exponential increase in archaeological field research in western Tian Shan. Most notable are the intensive surveys in the Bortala and Ili river valleys, including full-scale excavations at the sites of Aduuchuluu, Husita, Qialege'er, and Jirentai (IA CASS et al. 2013; Jia, Betts, Cong et al. 2017; Jia X. 2019; Wang and Ruan 2016; Wang Y. et al. 2019; XIA 2014a, 2017). These projects have generated a sizable comparative dataset useful for identifying different architectural patterns of habitation and burial in prehistoric western Xinjiang. Here, we give a preliminary analysis of the data presented in the previous sections. 
Most of the Bronze Age habitation structures in western Tian Shan are located in the foothills on south-facing piedmonts and river terraces flanking primary watercourses. The organization of habitation and burial structures is, however, different between the two river valleys. In Bortala Valley, habitation and burial structures are organized in distant, separate clusters, while they tend to be intermixed in larger congregations on second or third river terraces along Kashi River in Ili Valley. The difference in spatial layout may be attributed to differences in site function and seasonality. The upper valley Bortala sites are located within alpine and subalpine meadow zones with shrubs and sparse forest vegetation suited to the practice of seasonal pastoral nomadism. Similar to present-day winter pastures and encampments in the vicinity, these sites were probably selected for their south-facing leeward position (Cong and Jia 2019:225; Kuzmina 2007:44).

The highest concentrations of archaeological sites in Ili River Valley are found on loess-rich terrace grounds along the secondary tributaries of Ili River, where climatic conditions have been favorable for the development of agriculture even to today. The ecology is similar to the middle Bortala Valley, where the excavation of a large building complex and other types of structures at the Husita site reveals a site use pattern that may have been different from that of Aduuchuluu in the upper valley.

Aside from locational differences, distinct architectural forms can be discerned from among the broadly similar structures in the two valleys. In both regions, Bronze Age habitations are found to be subterranean buildings with a perimeter parapet wall constructed either of two rows of upright slabs as at Jirentai, Aduuchuluu, and Etuokesai'er Turigen (Fig. 3g) or stacked cobbles as at Kalasu (XIA et al. 2008). This type of construction is comparable to the "semi-subterranean houses" of Andronovo Culture found in Central Kazakhstan and the Orsk region, which E. E. Kuzmina (2007:42-43) describes as consisting of "large stone slabs set vertically on edge" and "stacked dry without mortar." Such houses are often "placed in two rows 'in bond", and clay mortar is sometimes employed and "the space between the two rows of slabs filled with rubble," as seen in the late Bronze Age phase of Tagibay-Bulak (Kuzmina 2007:42-43).

The habitation structures in Ili are more symmetrical than those in Bortala, with the line between the center hearth and the entrance forming a NE-SW central axis (Wang Y. et al. 2019:134) (Fig. 8a). ${ }^{4}$ The structures are supported by postholes on the building perimeter as well as at the center, which would have been required for a multipitched roof. In comparison, the absence of postholes in the large habitation structures in Bortala at ADCL I, ADCL II, and Husita suggests that half of each structure was covered by a flat or monopitched roof, while the other half was an open-air courtyard. These may be compared with Kuzmina's (2007:43) description of structures without postholes at the sites of Novoburino, Atasu, Shandahsa, and so on. This kind of interior division is still used in the seasonal encampments of pastoralists in Bortala today, where a single brick structure is partitioned into separate spaces for the main residence, hearth, cooking area, and corral (Cong and Jia 2019:223). Structures in Ili are equipped with well-built hearths, an interior feature that is usually represented in structures in Bortala by loosely placed stones around ash deposits.

It can be inferred from these architectural differences that sites in Ili were occupied for long periods of time by populations that were largely sedentary, whereas the Bortala structures were occupied seasonally during transhumant cycles of herd migration (Aduuduchuluu is still used as winter pasture today) (Caspari, Betts et al. 2017; Frachetti 2008; Honeychurch et al. 2007; Houle 2016). This is corroborated by 
material finds and the thickness of the cultural layers at the sites. For example, the F25 deposit at Jirentai is $2 \mathrm{~m}$ thick and comprises ten stratigraphic layers (Wang and Ruan 2019:134). The large quantities of animal bones, ceramic fragments, bronze implements, and sturdy hearth structures uncovered at Jirentai in Ili also suggest prolonged site occupation with houses built for year-round habitation or workshop production. The abundant coal deposits at Jirentai further suggest there might have been a resource incentive for extended stays. The Ili Basin is known for its rich coal resources and there are also a number of copper and iron mines in the Nulasai 奴拉賽 mountains (Nileke County) and the Awulale 阿吾拉勒 mountains (Xinyuan County) in the vicinity of the archaeological sites (CEC 2012; Mei and Li 1998; Wang L. et al. 2019). In comparison, there are fewer material remains at Aduuchuluu in Bortala. The lack of traces of intensive domestic activities suggests that the sites were used intermittently and for shorter periods of time.

Earthen and stone mounds are relatively uncommon at Aduuchuluu, but they are the most prevalent form of structure on the banks of the Kashi River in Ili Valley. Stone-slab burial enclosures like those in ADCL I and other sites in Bortala Valley such as Hala'ou 哈拉歐 are not found in this region (Fig. 3d). Instead, Bronze Age burials have predominately been discovered in earthen mounds. The burials are placed in a vertical pit furnished with a cist, stone-lined chamber, or wooden coffin (sometimes placed in a side chamber at the bottom of the pit). Human remains placed in the fetal position are found next to a range of burial objects including ceramic vessels, bronze mirrors, bronze earrings, and animal bones at Jirentai (Wang Y. et al. 2019; XIA 2017), Tangbalesayi (XIA 2012a, 2012b), and Tekesi (XIA 2012c).

Most round stone mounds or stone-overlaid earthen mounds have been identified as Iron Age or medieval period structures (Liu and Guan 2002; Zhang 1989; Zhang et al. 2012). These burials contain human remains laid in an extended position, painted pottery, and iron ornaments and weaponry associated with various steppe cultures of the first millennium B.C.E. These mounds are often found in a north-south chain formation on the first or second river terrace. The northern banks are generally more populated than the southern banks.

Standalone quadrilateral burial enclosures with upright slab walls are a structural type unique to Bortala River Valley (Fig. 3). SM4 and SM9 in ADCL Cemetery I are notable examples (Fig. 3c, Fig. 5). The perimeters of these burials are marked by erect stone slabs that are generally taller $(30 \mathrm{~cm}-1.2 \mathrm{~m}$ in height $)$ than they are wide. Most burials are encased in an east-west aligned cist made of slabs or stacked stones on four sides and occasionally lined with wood. The cists are covered by granite capstones, which in cases of secondary burials have often been displaced or damaged.

This type of square slab enclosure has also been found in the middle Bortala Valley. For example, SM3 (in the western part of Harulu Cemetery at Husita) is a square slab enclosure with a single grave sectioned into three cists containing cremated remains and a ceramic vessel. The other three burial structures excavated from Harulu are cobble-stone quadrilateral enclosures with east-west-oriented cists similar to those of the later periods at ADCL I Cemetery (Jia X. 2019:140, pl. 7:6). The radiocarbon dating of human remains from Harulu yielded a date range between the seventeenth and tenth centuries B.C.E. (Table 1).

While the northern zone of the ADCL I Cemetery features some prominent, single, stand-alone structures, compound quadrilateral enclosures are the most common structural type at both ADCL I and ADCL II cemeteries. These compound enclosures are 
characterized by an increase in the ratio of cist to enclosure and a decrease in the size of individual enclosures. The building structure also differs slightly from stand-alone structures. Instead of large upright slabs, perimeter walls are composed oflow-lying slabs and cobbles and they are often slanted rather than perfectly vertical. The enclosures are also less symmetrical than those of stand-alone structures. The number of cist graves inside each burial pit as well as the number of burial pits in each enclosure varies. Between one and three cist graves can be found inside a single pit, and they can contain different types of inhumations or cremations and primary or secondary burials with single or multiple individuals.

In ADCL II Cemetery, the structural connection between individual burial units is further intensified. Dated from the nineteenth to twelfth centuries B.C.E., multiple burial units are connected along their latitudinal and longitudinal axes into one large conglomerate (Table 2). Cobbles are used to fill the space between the slab cist and the perimeter of each enclosure (Fig. 7 bottom). Irrespective of the architectural forms and burial organization, the orientation of the interments is highly consistent. The long axis of the grave pit is almost always oriented east-west, while the capstones are positioned north-south. Where human remains are preserved, the head is positioned toward the western end facing north.

In axially aligned compound enclosures, the earliest enclosure may be identified by its slightly larger dimensions, while the annexes built later on are proportionately smaller. These annexes may be considered structural extensions of the original enclosure in that they use one of the existing walls as their new perimeter. This practice of appropriating earlier building components for later use is congruent with the construction of habitation structures at ADCL I, where existing structural components were also adapted for new buildings. For example, the walls of ADCL I-F1 were integrated into the perimeter of a later enclosure, ADCL I-F2. Cumulative constructions are a defining characteristic of khirigsuurs (a kind of Bronze Age funerary or commemorative structural complex with a central stone mound) in Mongolia, whereby each monument is an aggregate of heterogeneous structural components including radiating pavements and stone circles added to the complex over time. In the case of khirigsuurs, however, such additional parts were incorporated into a prescribed space according to their function and placement relative to the central mound, which had been configured for performances and participatory interactions (Allard and Erdenebaatar 2005; Wright 2012).

The Aduuchuluu structures adhere to a rather different architectural schema. It appears that aggregated constructions in Bortala were a resource-saving building strategy rooted in a deep tradition of placemaking. The spatial organization of burials and the design of grave structures show that social and kinship networks became more clearly defined and clan-based attachments to funerary and commemorative locales were strengthened over the course of two to three centuries (see radiocarbon ages from ADCL I Cemetery in Table 2). A time-honored funerary tradition was perpetuated by using the same structural form in increased density and connectivity. This may be attributed to the kind of “architectural conservatism" intrinsic to rituals (Hillier 1996:193, 306). Maintaining a locational and structural continuity to earlier, ancestral cemeteries while continuing to observe their geomantic orientations and cardinal directions appear to be the principal spatial principles of interment. If not purely a space-and-material saving tactic, the motivation behind building new burial structures with reduced dimensions relative to existing ones is likely to have been ancestor worship. 
It is also common to find habitation sites being appropriated for burial or other nonresidential use once they are abandoned. After ADCL I-F1 fell into disuse, a burial cairn was installed and cut into the original construction. This kind of site reuse is also observed at Qiongkeke in Ili, where an Iron Age burial superimposes on the original habitation structure (XIA 2002).

\section{CONCLUSION}

Field research on stone architecture in the river valleys of Bortala and Ili exemplifies a new momentum in Xinjiang archaeology. Intensive regional surveys and full-scale excavations, with the help of aerial photography, have brought about insights into the archaeological record of western Tian Shan beyond the classification of cultural types by burial accoutrements. In this article, we presented the results of archaeological expeditions at Aduuchuluu and Husita in Bortala River Valley and select sites along Kashi River in Ili Valley. We investigate the layout and forms of ground-level stone structures constructed of cobbles and rough-cut slabs that make up the landscape of a ubiquitous - but by no means uniform-archaeological feature in the Tian Shan steppe. Results of excavations show that the geometry of the structure on the surface often appears more homogeneous than what the subsurface architecture subsequently reveals. The permutations in how burials are configured, the reuse and extension of building parts, and the density of conglomerates differentiate the landscapes of Bortala and Ili. These distinctions do not stem solely from topographic differences but can be attributed to local conditions such as settlement duration, population size, social customs of land use, and funerary practice.

The archaeological assemblages of Aduuchuluu present a longitudinal view of clanbased seasonal pastoral encampments and funerary practice in the upper Bortala Valley. The structural expansion and reclamation of existing locales engender a staggered landscape in which architectural forms embody temporally intersecting spatial components of differential scales. In contrast, the arrangement of habitations in close formation with burial structures in Ili River Valley marks a landscape shaped by the highly sedentary activities of an agricultural economy supported by well-organized systems of production and exchange. The presence of well-built hearths and postholes alongside abundant animal remains and evidence of metal production at Jirentai indicates long-term site occupation. Husita in the middle Bortala Valley would lie somewhere between these two modes of habitation, as the structural remains and material finds uncovered thus far suggest prolonged periods of settlement with an agricultural economy based on animal husbandry. Andronovo's cultural influence is evinced in funerary practices and building designs, with archetypical subterranean buildings, ceramics, bronzewares, and positioning of interment found throughout Bronze Age sites in Ili and Bortala, albeit in different permutations and to varied extents (Han 2007; Jia, Betts, Cong et al. 2017; Ruan 2013; Shao 2009). The differential spatial configurations and temporal scales of the prehistoric structural remains of the two adjoining valleys are evidence of the distinctive adaptations of the expansive Andronovo on a small geographical scale. While the Andronovo question still looms large, it may prove tangential to the next stages of research. More constructive arguments may be sought by taking a more decentralized and holistic approach to dissecting the logic of building practices and space use in western Tian Shan. Specifically, we intend to incorporate other types of archaeological evidence 
such as petroglyphs, along with actualistic studies of stone construction and contemporary ethnographic fieldwork, into future analyses.

\section{ACKNOWLEDGMENTS}

Archaeological fieldwork and archival research for this article were supported by Tang Center of Early China (Columbia University), University of Pennsylvania Museum of Archaeology and Anthropology, the ACLS/Henry Luce Summer Pre-Dissertation grant, and the Chinese Academy of Social Sciences Innovation Project Fund (2013-30) for “新 疆博爾塔拉河流域青銅時代考古學文化的發現與研究 [The Discovery and Research of Bronze Age archaeological cultures in Bortala River Valley, Xinjiang]." Logistical support was generously provided by Wenquan County Bureau of Cultural Relics, Bortala Prefectural Museum, and Xinjiang Institute of Archaeology (Urumqi); regional survey data were supplied by Wenquan Bureau of Cultural Relics. We thank all past and present cohorts of the Bortala River Valley archaeological field project; without their contributions, data collection on such a geographical scale would not have been feasible. We are grateful to the four anonymous reviewers and the journal editors for making helpful suggestions that greatly improved the manuscript.

\section{NOTES}

1. Altitude measurements were taken from one of the geodetic control points.

2. In Chinese archaeological terminology, fangzhi is a generic term sometimes assigned in the field to any nonburial feature for which the function cannot yet be ascertained.

3. Similar hearth structures have been discovered at the Hu'ertuoleha 呼爾托勒哈 site in Bortala River Valley.

4. The orientation is indicated by a north arrow in figure 1 of Wang and Ruan (2016:n.p.). 
APPENDIX A: TRANSLITERATION OF TOPONYMS

\begin{tabular}{|c|c|c|c|c|c|}
\hline \multicolumn{2}{|c|}{ GEOGRAPHIC PLACE NAMES } & \multicolumn{2}{|c|}{ PRESENT-DAY ADMINISTRATIVE PLACE NAMES } & \multicolumn{2}{|c|}{ ARCHAEOLOGICAL SITE NAMES } \\
\hline CHINESE & OTHER & CHINESE & OTHER & CHINESE & OTHER \\
\hline PINYIN & TRANSLITERATIONS $^{\mathrm{a}}$ & PINYIN & TRANSLITERATIONS & PINYIN & TRANSLITERATIONS \\
\hline Aibi 艾比 & Ebi (M) & Aletai 阿勒泰 & Altai, Altay (M) & Adunqiaolu 阿敦喬魯 & Aduuchuluu (M) \\
\hline Alatao 阿拉套 & Alatau $(\mathrm{K})$ & Bo'ertala 博爾塔拉 & Bortala (M) & Aletengyemule 阿勒騰也木勒 & \\
\hline Awulale 阿吾拉勒 & & Gongliu 㠵留 & Toqquztara (U) & Ayousai 阿尤賽 & \\
\hline Bayinbuluke 巴音布魯克 & Bayanbulak (M) & Hejing 和静 & & $\begin{array}{l}\text { Etuokesai'er Turigen } \\
\text { 鄂托克塞爾吐日根 }\end{array}$ & \\
\hline Biezhentao 別真套 & Begijentao (M) & Kashi 喀什 & $\operatorname{Kax}(\mathrm{M})$ & Hala'ou 哈拉歐 & \\
\hline Boluokenu 博羅科努 & Borohoro $(\mathrm{M})$ & Nileke 尼勒克 & Nilka (M) & Harulu 哈如魯 & \\
\hline Dundeguole 敦德郭勒 & & Tekesi 特克斯 & Tekes (M) & Heishantou 黑山頭 & \\
\hline Gongnaisi 恐乃斯 & Künas (M) & Wenquan 溫泉 & Arixang $(\mathrm{M})$ & Hu'ertuoleha 呼爾托勒哈 & \\
\hline Ha'erketawu 哈爾克他烏 & & $\begin{array}{l}\text { Xinyuan 新源/ } \\
\text { Gongnaisi 鞏乃斯 }\end{array}$ & Künas (M) & Huoji’erte 霍吉爾特 & \\
\hline Huola 霍拉 & & Yili 伊犁 & Ili (M) & Husita 呼斯塔 & Khustai (M) \\
\hline Hongbielin 洪別林 & & Zhaosu 昭蘇 & Mongolküre (M) & Jirentai 吉仁台 & Jartai (M) \\
\hline E'erbin 額爾賓 & & Yining 伊寧 & Ghulja (M) & Kalasu 卡拉蘇 & Karasu (K) \\
\hline $\begin{array}{l}\text { Nulasai 奴拉賽 } \\
\text { Sailimu 賽里木 } \\
\text { Yilianhabi'erga 依連哈比爾尔 } \\
\text { Zhunga'er 準噶爾 }\end{array}$ & $\begin{array}{l}\text { Sayram (K) } \\
\text { Dzungaria (M) }\end{array}$ & & & $\begin{array}{l}\text { Kuokesu(he)xi 闊克蘇 (河) 西 } \\
\text { Ningjiahe Shuiku 寧家河水庫 } \\
\text { Qialege'er 恰勒格爾 } \\
\text { Qiongkeke 窮科克 } \\
\text { Tangbalesayi 湯巴勒薩伊 } \\
\text { Wutulan 烏土蘭 } \\
\text { Xiabandi 下坂地 }\end{array}$ & \\
\hline
\end{tabular}

${ }^{\mathrm{a}} \mathrm{K}=$ Kazakh, $\mathrm{M}=$ Monglian, $\mathrm{U}=$ Uyghur. 


\section{REFERENCES CITED}

Allard, Francis, and Dimajajav Erdenebaatar

2005 Khirigsuurs, ritual and mobility in the Bronze Age of Mongolia. Antiquity 79(305):547-563.

Bourgeois, J., D. V. Cheremisin, G. Plets, E. P. Dvornikov, A. V. Ebel, B. Stichelbaut, L. van Hoof, AND W. GHEYLE.

2014 An archaeological landscape in the Dzhazator Valley (Altai Mountains): Surface monuments and petroglyphs from the Chalcolithic to the Ethnographic Period. Archaeology, Ethnology and Anthropology of Eurasia 42(4):106-119.

${ }^{14}$ C Lab IA CASS, Radiocarbon Lab-PU, and Radiocarbon Lab-LU [ZhongGuo Shehui Kexueyuan KAOGUYANJIUSUO KeJIKAOGUZHONGXI TANSHISI SHIYANSHI 中國社會科學院考古研究所科技考古中心 碳十四實驗室 ( ${ }^{14} \mathrm{C}$ Laboratory of THE Center for Scientific ArChaeology, IA CASS), Beijing Daxue Kaoguwenbo Xueyuan Tanshisi Shiyanshi 北京大學考古文博學院碳十四實驗室 (RADiOCARbon Laboratory of Peking University), and Lanzhou DaXue JiasuQi Tanshisi Shiyanshi 蘭州大學 加速器碳十四實驗室 (RADIOCARBON LABORATORY OF LANZHOU UNIVERSITY)]

2019 Fangshexing tansu ceding niandai baogao (si-wu) 放射性碳素測定年代報告 (四五) [Radiocarbon dating report (4-5)]. Kaogu 考古 7:92-95.

Caspari, Gino, Alison Betts, and Peter Weiming Jia

2017 The Bronze Age in the western Tianshan, China: A new model for determining seasonal use of sites. Journal of Archaeological Science: Reports 14:12-20.

Caspari, Gino, Gertjan Plets, Timo Balz, and Bihong Fu

2017 Landscape archaeology in the Chinese Altai: Survey of the Heiliutan Basin. Journal of Archaeological Research in Asia 10:48-53.

CEC [Zhongguo Dianli Qiye Lianhehui 中國電力企業聯合會 (China Electricity Council)]

2012 新疆伊犁盆地探明煤炭資源儲量 558 亿吨 Xinjiang Yili pendi tanming meitan ziyuan chuliang 558 yi dun [Coal reserves discovered in Ili Basin in Xinjiang amounts to 55.8 billion tons], in China Electricity Council (website), URL: www.cec.org.cn/xiangguanhangye/201207-23/87723.html.

Chan, ANNIE

2017a Out of Place: Stone Architecture and Pastoral Nomadism in Prehistoric Inner Asia. Unpublished Ph.D. diss. University of Pennsylvania.

2017 b From milk and wool: Vital pastoral crafts and their vitality in 21 st century Xinjiang. Journal of Ethnobiology 37(3):542-560.

CHEN GE 陳戈

1990 Guanyu Xinjiang diqu de qingtong shidai he zaoqi tieqi shidai wenhua 關於新疆地區時代和 早期鐵器時代文化 [Concerning the Bronze and Early Iron Age cultures in Xinjiang Uyghur Autonomous Region]. Kaogu 考古 4:322, 343-351.

2017 Xinjiang Kaogu Lunwenji, shang, xia 新疆考古論文集上, 下 [The Archaeology of Xinjiang: Collected Papers, vol. 1 and 2]. Beijing: Shangwu yinshuguan 商務印書館.

Chen, Kwang-tzuu, and Fredrik T. Hiebert

1995 The late prehistory of Xinjiang in relation to its neighbors. Journal of World Prehistory 9 (2):243-300.

CHEN ZHIJUN 陳志軍, ZHANG JiNG 張晶, KAMILA 卡米拉, AND MA YONG 馬勇

2007 Bo'ertala heliu shuiwen texing 博爾塔拉河流水文特性 [The hydrological characteristics of the Bortala River drainage basin]. Shui ziyuan yanjiu 水資源研究 1:1-9.

Cong Dexin 从德新

2016 Xinjiang Wenquan Adunqiaolu yizhi de fajue: 2015 nian shehui kexueyuan kaogusuo tianye kaogu chengguo (ershier) 新疆溫泉阿敦喬魯遺址的發掘: 2015 年社會科學院考古研究所 田野考古成果 (二十二) [The results of archaeological field excavations by the Institute of Archaeology, Chinese Academy of Social Sciences, at the site of Aduuchuluu in Wenquan County in 2015 (no. 22)]. Kaogu [Chinese Archaeology] (29/01/16). URL: www.kaogu.cn/ $\mathrm{cn} / \mathrm{xccz} / 20160129 / 52971$.html.

Cong Dexin 丛德新 AND Jia Weiming 賈偉明

2019 Shiqian shengye moshi de huanjing kaoguxue guancha: Yi Xinjiang Wenquan Adunqiaolu yizhi weili 史前生業模式的環境考古學觀察一以新疆溫泉阿敦喬魯遺址為例 [Environmental 
archaeology on prehistoric subsistence economies: A case study of the Adunqiaolu site in Xinjiang, China]. Disiji Yanjiu 第四紀研究 [Quaternary Sciences] 39(1):218-227.

Cong Dexin 从德新, Jia Weiming 賈偉明, Alison Betts, and Paula Doumani

2017 Adunqiaolu: Xitianshan diqu qingtong shidai yicun xinleixing 阿敦喬魯: 西天山地區青銅時 代遺存新類型 [Aduuchuluu: Remains of a new Bronze Age archaeological typology in Western Tian Shan]. Xiyuyanjiu 西域研究 4:15-27.

Fitzhugh, WILLIAM

2009 Pre-Scythian ceremonialism, deer stone art, and cultural intensification in Northern Mongolia, in Social Complexity in Prehistoric Eurasia: Monuments, Metals and Mobility: 378-411, ed. Bryan K. Hanks and Katheryn M. Linduff. Cambridge, UK: Cambridge University Press.

Frachetti, Michael D.

2008 Pastoralist Landscapes and Social Interaction in Bronze Age Eurasia. Berkeley: University of California Press.

GuO Wu 郭物

2011 Xinjiang shiqian wanqi shehui de kaogu yanjiu 新疆史前晚期社會的考古研究 [Archaeological Research of Late Prehistoric Societies in Xinjiang]. Shanghai: Shanghai guji chubanshe 上海古 籍出版社.

HAN JIANYE 韓建業

2007 Xinjiang de qingtong shidai he zaoqi tieqi shidai wenhua 新疆的青銅時代和早期鐵器時代文化 [The Bronze and Early Iron Age Cultures of Xinjiang]. Beijing: Wenwu chubanshe 文物出版 社

Hillier, Bill

1996 The Space is the Machine. Cambridge, UK: Cambridge University Press.

Honeychurch, William, Joshua Wright, and Chunag Amartuvshin

2007 A nested approach to survey in the Egiin Gol Valley, Mongolia. Journal of Field Archaeology 32:369-383.

Houle, JEAN-Luc

2016 The killing season: Ethnographic and zooarchaeological perspectives on residential mobility in Bronze Age Mongolia, in People with Animals: Perspectives and Studies in Ethnozooarchaeology: 65-76, ed. Lee Broderick. Oxford: Oxbow Books.

IA CASS, Bo'ertala, and WenquanXian [Zhongguo Shehui Kexueyuan Kaogu Yanjiusuo 中國社會 科學院考古研究所 (Institute of Archaeology, Chinese Academy of Social Sciences), Bo'ertala MENGGU ZiZHIZHOU BowUGUAN 博爾塔拉蒙古自治州博物館, AND WENQUANXIAN WENWUJU 溫泉縣 文物局]

2013 Xinjiang Wenquanxian Adunqiaolu yizhi yu mudi 新疆溫泉縣阿敦喬魯遺址與墓地 [The habitation site and cemetery of Aduuchuluu in Wenquan County, Xinjiang Uyghur Autonomous Region]. Kaogu 考古 7:24-30.

Jia, Peter Weiming, and Alison Betts

2010 A re-analysis of the Qiemu'erqieke (Shamirshak cemeteries), Xinjiang, China. Journal of IndoEuropean Studies 38(3-4):275-317.

Jia, Peter Weiming, Alison Betts, and Idilisi Abuduresule

2019 A new hypothesis for early Bronze Age cultural diversity in Xinjiang, China. Archaeological Research in Asia 17:204-213.

Jia, Peter Weiming, Alison Betts, Dexin Cong, Xiaobing Jia, and Paula Doumani Dupuy

2017 Adunqiaolu: New evidence for the Andronovo in Xinjiang, China. Antiquity 91(357): 621-639.

Jia, Peter Weiming, Alison Betts, Paula N. Doumani Dupuy, Dexin Cong, and Xiaobing Jia

2018 Bronze Age hill forts: New evidence for defensive sites in the western Tian Shan, China. Archaeological Research in Asia 15:70-81.

JIA XIAOBING 賈笑冰

2019 Xinjiang Wenquan-xian Husita yizhi fajue de zhuyao shouhuo 新疆溫泉縣呼斯塔遺址發掘 的主要收穫 [Key results of excavations at Husita, Wenquan County, Xinjiang Uyghur Autonomous Region]. Xiyu yanjiu 西域研究 1:139-141, color plates 7, 8.

Kovalev, A. A.

2005 Chemurchekskiy kul'turnyy fenomen: yego proiskhozhdenne i rol' v formirovanii kul'tur zpokhi ranney bronzy Altaya i Tsentral'noy Azii [The cultural phenomenon of Chemurchek: 
Its origin and role in the formation of cultures in the Early Bronze Age of the Altai and Central Asia], in Zapadnaya i Yuzhnaya Sibir'v drevnosti: Sbornik nauchnykh trudov, posvyashchennyy 60letiyu so dnya rozhdeniya Yuriya Fedorovicha Kiryushina [Western and Southern Siberia in Antiquity: Collection of Scientific Works Dedicated to the 60th Anniversary of the Birth of Yuri Fedorovich Kiryushin]: 178-184. Barnaul: Altai State University Press.

Kubarev, V. D.

2009 Pamyatniki Karakolskoi kultury Altaya [Monuments of the Karakol Culture of the Altai]. Novosibirsk: Izd. IAE SO RAN.

Kuzmina, Elena E.

2007 The Origins of Indo-Iranians. Leiden Indo-European Etymological Dictionary Series. Leiden: Brill.

Li JINGUO 李金國 AND LÜ ENGUO 呂恩國

2003 Wenquan xian Adunqiaolu yicun de kaogu diaocha he yanjiu 溫泉縣阿敦喬魯遺存的考古調 查和研究 [Investigation and research of archaeological remains at Adunqiaolu in Wenquan County]. Xinjiang Wenwu 新疆文物 1:20-27.

Li Yumei 李玉梅, Yang Zhenjing 楊振京, Zhang Yun 張芸, Yang Qinghua 楊慶華, Liu Linjing 劉林敬, BI ZHIWEI 畢志偉, WANG CHENGMIN 王成敏, KONG ZHAOCHEN 孔昭宸, AND ZHAO LONG 趙龍 2014 Xinjiang Bo'ertala-he biaotu baofen zhuhe yu zhibei guanxi yanjiu 新疆博爾塔拉河表土狍 粉組合與植被關係研究 [A study of the relationship between the composition of surface soil pollen and the vegetation of Bortala River in Xinjiang]. Scientia Geographica Sinica 34 (12):1518-1525.

LIN YUN 林沄

2011 Silu Kaitong zhiqian Xinjiang de Jiaotong Luxian 絲路開通之前新疆的交通路線 (Routes of transportation in Xinjiang before the Silk Roads). Caoyuan Wenwu 草原文物 1:55-64.

LiU XUETANG 刘學堂 AND GUAN BA 關巴

2002 Xinjiang Yili hegu shiqian kaogu de zhongyao shouhuo 新疆伊犁河谷史前考古的重要收穫 [Key research results of prehistoric archaeology in Ili River Valley, Xinjiang]. Xiyu yanjiu 西域 研究 4:106-108.

LUAN Fuming 欒福明, WANg FANG 王芳, AND XIONG HeIGANG 熊黑鋼

2017 Yili hegu wenhua yizhi shikong fenbu ji dili beijing yanjiu 伊犁河谷文化遺址時空分布及地 理背景研究 [Research on the geography and spatial-temporal distribution of the sites of the Ili River Valley Culture]. Ganhanqu Dili 乾旱區地理 [Arid Land Geography] 40(1):211-221.

Mei JiAnJun 梅建軍 AND COLIN SHell

1999 The existence of Andronovo Cultural influence in Xinjiang during the 2nd millennium BC. Antiquity 73(281):570-578.

2002 The Iron Age cultures in Xinjiang and their steppe connections, in Ancient Interactions: East and West in Eurasia: 213-236, ed. K. Boyle, C. Renfrew, and M. Levine. Cambridge: McDonald Institute Monographs.

MEI JiANJUN 梅建軍 AND Li YANXIANG 李延祥

1998 Xinjiang Nulasai gutongkuangye yizhi yelian jishu chubu yanjiu 新疆奴拉赛古铜矿冶遗址 治炼技术初步研究 [A preliminary study of smelting technology at the Nulasai copper site in Xinjiang]. Zirakexueshi Yanjiu 自然科學史研究 [Studies in the History of Natural Sciences] 3:289-295.

MiYamoto, KazUO

2016 Chronology of stone-slab graves in Mongolia based on excavation results from Daram and Tevsh sites, in Excavations at Daram and Tevsh Sites: 76-83, ed. Kazuo Miyamoto and Hiroki Obata. Kyushu: Kyushu University.

Plets, Gertjan, Wouter Gheyle, Geert Verhoeven, Jeroen De Reu, Jean Bourgeois, Jeroen Verhegge, and Birger Stichelbaut

2012 Three-dimensional recording of archaeological remains in the Altai Mountains. Antiquity 86 (333):884-897.

RUAN QIURONG 阮秋榮

20122010 nian Xinjiang Yili-he liuyu kaogu xin shouhuo 2010 年新疆伊犁河流域考古新收穫 [New results from archaeological investigations in Ili River Valley in 2010], in Yili hegu kaogu wenjin 伊犁河谷考古文集 [A Collection of Essays on the Archaeology of Ili River Valley]: 435-439, ed. Wang Linshan 王林山. Urumqi: Xinjiang Daxue Chubanshe 新疆大學出版社. 
2013 Xinjiang faxian de Andeluonuo wenhua yicun 新疆發現的安德羅諾文化遺存 [Archaeological remains of Andronovo Culture discovered in Xinjiang]. Xibu Kaogu 西部考古 $7: 125-154$.

Rudkovsky, I. V.

2013 Andronovskaya Ornamentika v Kontekste Sistemoobrazuyushchikh Invariantov [Andronovo ornamentation in the context of system-forming invariants]. Almaty: Institute of Archaeology of O.H. Margulan, Committee of Science, Ministry of Education and Science of the Republic of Kazakhstan.

Seitsonen, Oula, Jean-Luc Houle, and Lee G. Broderick

2014 GIS approaches to past mobility and accessibility: An example from the Bronze Age Khanuy Valley, Mongolia, in Past Mobilities: Archaeological Approaches to Movement and Mobility: 79-111, ed. J. Leary. Farnhem: Ashgate Publishing.

SHAO HUIQIU 邵會秋

2008 Shilun Xinjiang Aletai diqu de lianglei qingtong wenhua 試論新疆阿勒泰地區的兩類青銅 文化 [An Analysis of Two Bronze Cultures in the Altai Region, Xinjiang]. Xiyu yanjiu 西域研 究 4:59-65.

2009 Xinjiang diqu Andenuowo wenhua xiangguan yicun tanxi 新疆地區安德諾沃文化相關遺存 探析 [On remains associated with Andronovo Culture in Xinjiang]. Bianjiang Kaogu yanjiu 邊疆考古研究 [Research of China's Frontier Archaeology] 8:81-97.

TAN YUHUA 譚玉華

2011 Xinjiang Tashiku'ergan-xian Xiabandi AII mudi xinshi 新疆塔什庫爾干縣下坂地 AII 墓地 新識 [New insights into Xiabandi Cemetery AII in Tashkurgan Tajik Autonomous County, Xinjiang]. Xiүu yanjiu 西域研究 3:83-90.

WANG BO 王博 AND Qi XIAOSHAN 祁小山

1995 Xinjiang shiren de leixing fenxi 新疆石人的類型分析 [A typological analysis of anthropomorphic statues in Xinjiang]. Xiүu yanjiu 西域研究 4:67-76.

Wang, Lu, Fan Chen, Yongqiang Wang, Wei Qian, Jianjun Mei, Marcos Martinón-Torres, and Kunlong Chen

2019 Copper metallurgy in prehistoric Upper Ili Valley, Xinjiang, China. Archaeological and Anthropological Sciences 11:2407-2417.

WANG MingZHE 王明哲

2013 Lun Ke'ermuqi wenhua he Ke'ermuqi mudi de shidai 論克爾木齊文化和克爾木齊墓地的 時代 [On the chronology of Qi'ermuqieke Culture and Qie'ermuqieke cemetery]. Xiyu Yanjiu 西域研究 2:69-80.

WANG YONGQIANG 王永強 AND RUAN QIURONG 阮秋榮

20162015 nian Xinjiang Nileke-xian Jirentai gouko kaogu gongzuo de xinshouhuo 2015 年新疆尼 勒克縣吉仁台溝口考古工作的新收穕 [New results from archaeological investigations at Jirentai, Nikleke County, Xinjiang Uyghur Autonomous Region in 2015]. Xiyu Yanjiu 西域 研究 1:132-135.

WANG YONGQIANG 王永強, YUAN XIAO 袁曉, AND RUAN QIURONG 阮秋榮

2019 Xinjiang Nileke-xian Jirentai goukou yizhi 2015-2018 nian kaogu shouhuo ji chubu renshi 新疆尼勒克縣吉仁台溝口遺址 2015-2018 年考古收穫及初步認識 [Preliminary results of field investigations (2015-2018) at the Jirentai-goukou site in Nileke County, Xinjiang]. Xiyu yanjiu 西域研究 1:133-138.

Wenquan Xian Difang Weiyuanhui 温泉縣地方委員會 [Wenquan County Local CounciL]

2003 Wenquan Xianzhi 溫泉縣志 [Wenquan County Annals]. Urumqi: Xinjiang Renmin Chubanshe 新疆人民出版社.

WRIGHT, JOSHUA

2012 Landscapes of inequality? A critique of monumental hierarchy in the Mongolian Bronze Age. Asian Perspectives 51(2):139-163.

XIA [XINJiAng Kaggu YanjIUSUO 新疆文物考古研究所 (XINJIANG InSTITUTE OF ARChaeOlogy)]

1981 Xinjiang Ke'ermuqi gumuqun fajue jianbao 新疆克爾木齊古墓群發掘簡報 [A preliminary report of the excavations of the burials of Ke'ermuqi in Xinjiang]. Wenwu 文物 1:23-32. 
2002 Nileke-xian Qiongkeke yihao mudi kaogu fajue baogao 尼勒克縣窮科克一號墓地考古發 掘報告 [Archeological excavation report of Qiongkeke Cemetery No. 1 in Nileke County]. Xinjiang Wenwu 新疆文物 3-4:13-53.

$2012 a$ Nileke-xian Tangbalesayi mudi kaogu fajue baogao 尼勒克縣湯巴勒薩伊墓地考古發掘報告 [The archaeological report of excavations at Tangbalesayi Cemetery in Nileke County]. Xinjiang $W e n w u$ 新疆文物 2:4-20.

$2012 b$ Xinjiang Yili Nileke Tangbalesayi mudi 新疆伊犁尼勒克湯巴勒薩伊墓地 [Preliminary report of the site of Tangbalesayi Cemetery in Ili Prefecture, Xinjiang]. Wenwu 文物 5:13-22.

2012c Xinjiang Tekesixian Kuokesuxi erhao muqun de fajue 新疆特克斯縣闊克蘇西二號墓群的 發掘 [The excavation of no. 2 cemetery at the site of Kuokesuxi in Tekesi County, Xinjiang]. Kaogu 考古 9:3-16.

2012d Xinjiang Tekesixian Kuokesuxi erhao muqun kaogu fajue jianbao 新疆特克斯縣闊克蘇西 2 號墓群考古發掘簡報 [Preliminary report of excavations of Kuokesuxi Cemetery no. 2 in Tekesi County, Xinjiang]. Xinjiang Wenwu 新疆文物 2:51-67.

2012e Xinjiang Xiabandi mudi 新疆下坂地墓地 [Xiabandi Cemetery in Xinjiang] Beijing: Wenwu chubanshe 文物出版社.

2013 Xinjiang Ayousai goukou yizhi kaogu fajue jianbao 新疆阿尤賽溝口遺址考古發掘簡報 [A preliminary excavation report of the site of Ayousai Goukou, Xinjiang]. Xinjiang Wenwu 新疆 文物 2:4-10.

$2014 a$ Qialege'er yizhi kaogu fajue jianbao 恰勒格爾遺址考古發掘簡報 [A preliminary excavation report of the site of Qialege'er]. Xinjiang Wenwu 新疆文物 1:32-35.

$2014 b$ Nileke-xian Wutulan mudi kaogu fajue baogao 尼勒克縣烏土蘭墓地考古發掘報告 [The excavation report of Wutulan cemetery in Nileke County]. Xinjiang Wenwu 新疆文物 $1: 36-57$.

2017 Xinjiang Nileke Jirentai goukou yizhi fajue jianbao 新疆尼勒克吉仁台溝口遺址發掘簡報 [A preliminary excavation report of the site of Jirentai in Nileke County]. Kaogu 考古 7:57-70.

2018 Xinjiang qingtong shidai zhi tieqi shidai kaogu yicun de yanjiu 新疆青銅時代至鐵器時代考 古遺存的研究 [Research on the archaeology of Bronze and Iron Age Xinjiang], report presented by Ruan Qiurong at the 2017 New Archaeological Discoveries in Xinjiang Project Briefing, 5-6 February 2018, Urumqi, China.

XIA, Yili, and Nileke [Xinjiang Kaogu Yanjiusuo 新疆文物考古研究所 (Xinjiang Institute of ArChaeology), Yili Hasake Zizhizhou Wenwuju 伊犁哈萨克自治州文物局 (Ili KaZAKh Autonomous Prefectural Bureau of Cultural Relics), and Nileke Xian Wenwuju 尼勒克縣文物局 (Nileke County Institute for the Management of Cultural Relics)]

2008 Nileke-xian Kalasu yizhi kaogu fajue jianbao 尼勒克縣卡拉蘇遺址考古發掘簡報 [A preliminary excavation report of the site of Kalasu in Nileke County]. Xinjiang Wenwu 新疆文物 3-4.

Xinjiang Cultural Bureau [Xinjiang Weiwu'er Zizhiqu Wenwuju 新疆維吾爾自治區文物局 (Xinjiang Uyghur Autonomous Region Bureau of Cultural Relics)]

2011 a Xinjiang Weiwu'er zizhiqu disanci quanguo wenwu pucha ziliao huibian. Wenquanxian buke yidong wenwu 新疆維吾爾自治區第三次全國文物普查資料匯編. 溫泉縣不可移動文物 [Compilation of the Third National Census of Cultural Relics in Xinjiang Uyghur Autonomous Region: The Immovable Cultural Relics of Wenquan County]. Internal unpublished report, available from Wenquan County Cultural Bureau.

2011 B Bo'ertala Menggu zizhizhou juan: Xinjiang weiwu'er zizhiqu disanci quanguo wenwu pucha chengguo jicheng 博爾塔拉蒙古自治州卷. 新疆維吾爾自治區第三次全國文物普查成果集成 [Volume on Bortala Mongol Autonomous Prefecture: A Compendium of Results of the Third National Survey of Cultural Relics in Xinjiang Uyghur Autonomous Region]. Beijing: Kexue chubanshe 科學出版社.

Xinjiang Museum [Xinjiang Weiwu'er Zizhiqu Bowuguan 新疆維吾爾自治區博物館 (Xinjiang Uyghur Autonomous Region Museum)]

1995 Bo’ertala Menggu Zizhizhou zhongyao guchengzhi he gumuzang diaocha 博爾塔拉蒙古自 治州重要古城址和古墓葬調查 [Survey of important ancient city sites and ancient burials in Bortala Mongol Autonomous Prefecture], in Xinjiang Wenwu Kaogu Xinshouhuo 新疆文物考 古新收穫 (1979-1989) [New Findings in Xinjiang Archaeology and Cultural Relics 
(1979-1989)]：593-597, ed. Xinjiang Wenwu Kaogu Yanjiusuo 新疆文物考古研究所 [Xinjiang Institute of Archaeology]. Urumqi: Xinjiang Renmin Chubanshe 新疆人民 出版社.

YANG JiANHUA 楊建華, SHAO HUIQIU 邵會秋, AND PAN LiNG 潘玲

2015 Ouya caoyuan dongbu de jinshu zhi lu: Sichou zhi lu yu Xiongnu lianmeng de yunyu guocheng 歐亞草 原東部的金屬之路: 絲綢之路與匈奴聯盟的孕育過程 [The Metal Road of the Eastern Eurasian Steppe: The Birth of the Silk Road and the Xiongnu Empire]. Shanghai: Shanghai guji chubanshe 古籍出版社.

ZHANG YUZHONG 张玉忠

1989 Yili-hegu tudunmu de faxian he yanjiu 伊犁河谷土墩墓的發現和研究 [The discovery and research of earthen mounds in Ili River Valley]. Xinjiang Wenwu 新疆文物 3:11-22.

ZHANG YuZhong 張玉忠, GuO Dexing 郭德興, AND ZhaO DerONG 趙德榮

2012 Yili diqu wenwu pucha baogao 伊犁地區文物普查報告 [A survey report of cultural relics in the Ili Region], in Yili Hegu Kaogu Wenjin 伊犁河谷考古文集 [A Collection of Essays on the Archaeology of Ili River Valley]: 16-75, ed. Wang Linshan 王林山. Urumqi: Xinjiang Daxue Chubanshe 新疆大學出版社.

ZHAO JIAN'AN 赵建安, ZHANG YING 張英, AND LIU FANG 劉芳

2009 Gudai Xinjiang Yilihe liuyu nongye tudi ziyuan liyong ji qishi 古代新疆伊犁河流域農業土 地資源利用及啟示 [The use of agricultural land resources in Ili River Basin in ancient Xinjiang and its implications]. Ziyuan Kexue 資源科學 31(12):2047-2054. 